CHANNEL INFILTRATION FROM FLOODFLOWS ALONG THE PAWNEE RIVER AND ITS TRIBUTARIES, WEST-CENTRAL KANSAS

By J.B. Gillespie and C.A. Perry

U.S. GEOLOGICAL SURVEY

Water-Resources Investigations Report 88-4055

Prepared in cooperation with the

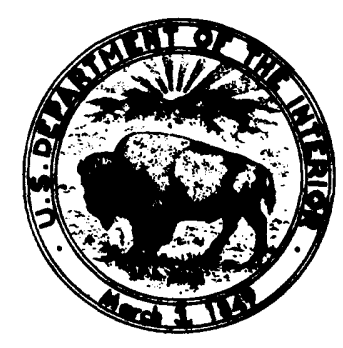

U.S. SOIL CONSERVATION SERVICE, PAWNEE WATERSHED DISTRICT NO.81, and SOUTHWEST KANSAS GROUNDWATER MANAGEMENT DISTRICT NO. 3

Lawrence, Kansas 
DEPARTMENT OF THE INTERIOR

\section{DONALD PAUL HODEL, Secretary}

U.S. GEOLOGICAL SURVEY

Dallas L. Peck, Director

For further information write to:

District Chief

U.S. Geological Survey

1950 Constant Ave - Campus West

Lawrence, Kansas 66046
Copies of this report can be purchased f rom:

U.S. Geological Survey

Books and Open-File Reports

Federal Center

Box 25425, Building 810

Denver, Colorado 80225 


\section{CONTENTS}

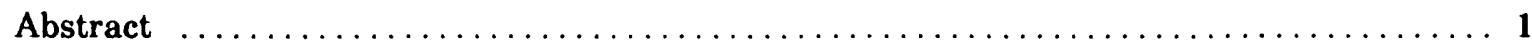

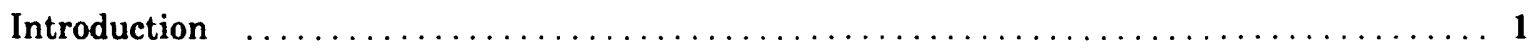

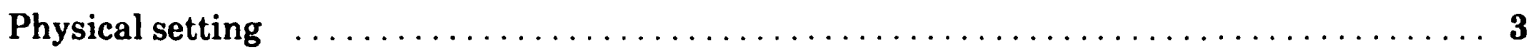

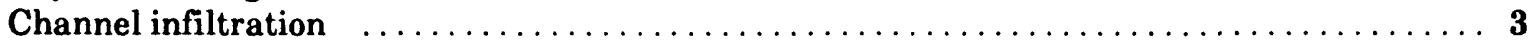

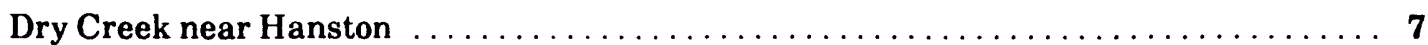

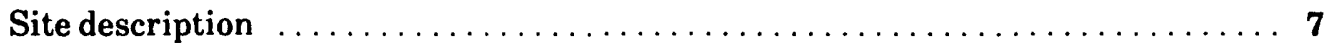

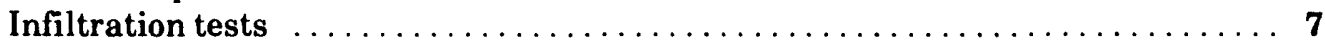

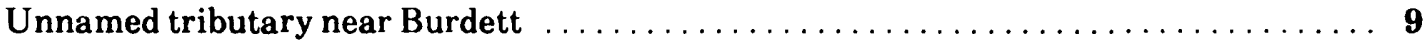

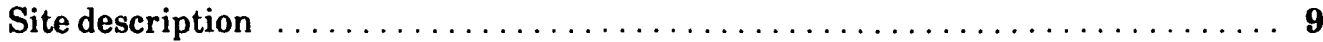

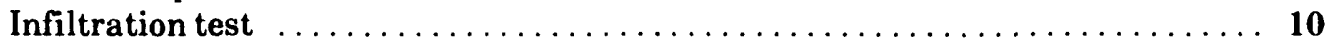

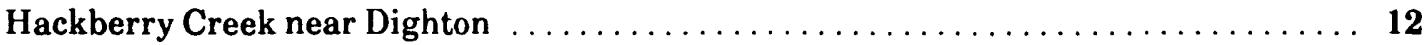

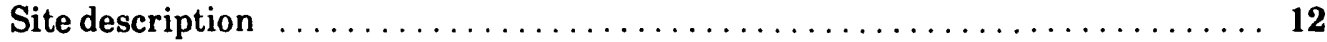

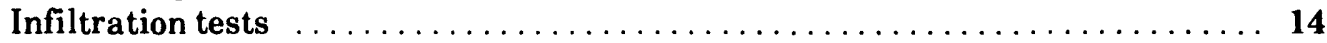

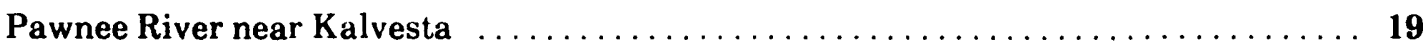

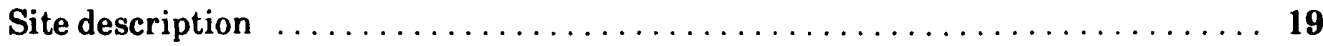

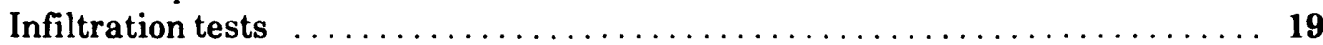

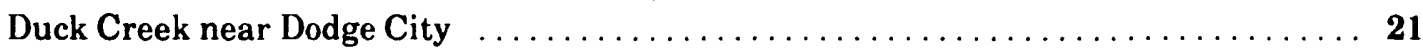

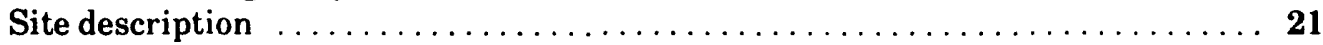

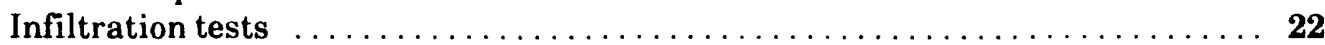

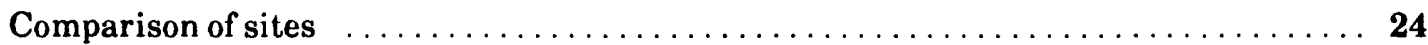

Estimated channel infiltration from simulated floodflows $\ldots \ldots \ldots \ldots \ldots \ldots \ldots \ldots \ldots$

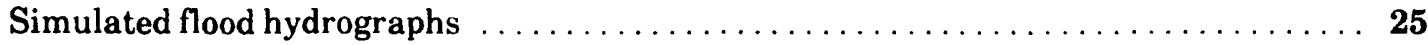

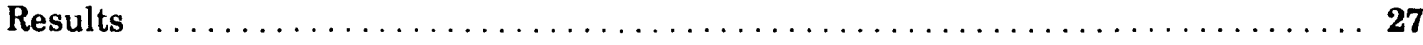

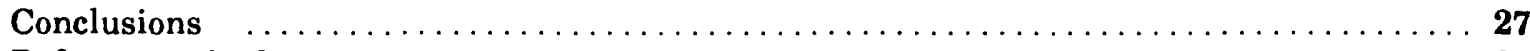

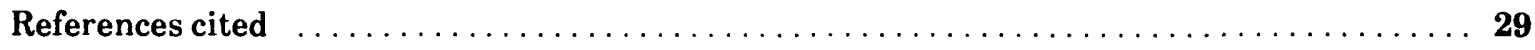

FIGURE $\quad$ Page

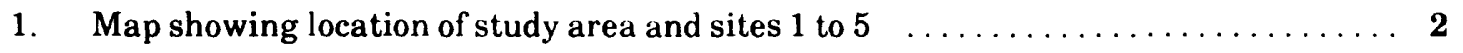

2. Block diagram showing construction details of channel infiltrometer and location of

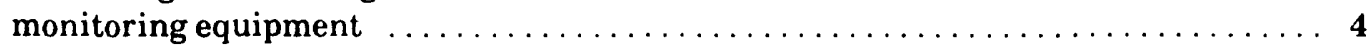

3. Photograph showing channel infiltrometer and monitoring equipment at site $3 \ldots \ldots$

4-10. Graphs showing:

4. Gamma, neutron, and lithologic logs, channel configuration, and location of test hole, potentiometers, and neutron-probe access tube at site $1 \ldots \ldots \ldots \ldots \ldots \ldots \ldots$

5. Water level in channel infiltrometer and shallow potentiometer during test 1 at site 18

6. Neutron logs from neutron-probe access tube at site $1 \ldots \ldots \ldots \ldots \ldots \ldots$

7. Infiltration rate as a function of stage and time in channel infiltrometer during test 1

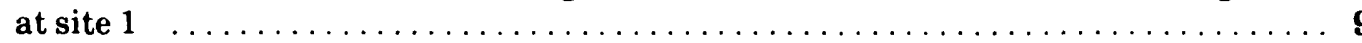

8. Water level in channel infiltrometer and shallow potentiometer and infiltration rate during test 2 at site 1 


\section{CONTENTS--Continued}

FIGURE

9. Infiltration rate for double-ring infiltrometers at site 1

10. Gamma, neutron, and lithologic logs, channel configuration, and location of test hole, potentiometers, and neutron-probe access tube at site 2

11. Photograph showing channel infiltrometer at site 2

12-33. Graphs showing:

12. Water level in channel infiltrometer and shallow potentiometer and infiltration rate

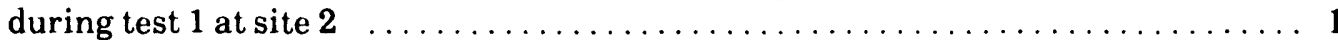

13. Neutron logs from neutron-probe access tube at site $2 \ldots \ldots \ldots$

14. Infiltration rate for double-ring infiltrometers at site $2 \ldots \ldots \ldots \ldots$

15. Gamma, neutron, and lithologic logs, channel configuration, and location of test hole, potentiometers, and neutron-probe access tubes at site 3

16. Water level in channel infiltrometer and shallow potentiometer during tests 1 and 2

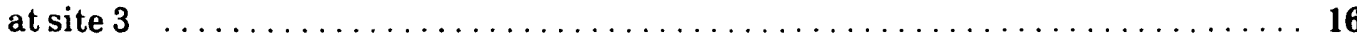

17. Neutron logs from neutron-probe access tube at site $3 \ldots \ldots \ldots$

18. Infiltration rate as a function of stage and time in channel infiltrometer during test 1 at site 3

19. Infiltration rate as a function of stage and time in channel infiltrometer during test 2 at site $3 \ldots \ldots \ldots \ldots \ldots \ldots \ldots \ldots \ldots \ldots \ldots \ldots \ldots \ldots \ldots \ldots \ldots \ldots \ldots$

20. Infiltration rate for double-ring infiltrometers at site $3 \ldots \ldots \ldots$

21. Gamma and lithologic logs, channel configuration, and location of test hole and potentiometer at site 4

22. Water level in channel infiltrometer and potentiometer during test 1 at site $4 \ldots \ldots$

23. Infiltration rate as a function of stage and time in channel infiltrometer during test 1 at site 4

24. Water level in channel infiltrometer during tests 1 and 2 at site $4 \ldots \ldots \ldots$

25. Infiltration rate in channel infiltrometer during test 2 at site 4

26. Gamma, neutron, and lithologic logs, channel configuration, and location of test hole, potentiometers, and neutron-probe access tube at site 5

27. Water level in channel infiltrometer during tests 1 and 2 at site 5 


\section{CONTENTS--Continued}

FIGURE

28. Neutron logs from neutron-probe access tube at site 5

29. Infiltration rate as a function of stage and time in channel infiltrometer during tests 1 and 2 at site 5

30. Infiltration rate for double-ring infiltrometers at site 5

31. Flood duration-peak discharge relation for Guzzlers Gulch near Ness City, station number 07140700

32. Relation between uncontrolled and controlled flood hydrographs for sites 3 and 5 .

33. Cumulative infiltration along channel at sites 1 to 5 as a function of simulated flood volumes

TABLE

1. Infiltration volumes for simulated floodflows at sites 1 to 5

\section{CONVERSION FACTORS}

For those interested readers, the factors for converting the inch-pound units used in this report to metric (International System) are given below:

$\begin{array}{lcl}\text { Multiply inch-pound unit } & B y & \text { Toobtain metric unit } \\ \text { inch } & 25.4 & \text { millimeter } \\ \text { foot } & 0.3048 & \text { meter } \\ \text { mile } & 1.609 & \text { kilometer } \\ \text { square mile } & 2.590 & \text { square kilometer } \\ \text { gallon } & 3.785 & \text { liter } \\ \text { acre-foot } & 1,233 & \text { cubic meter } \\ \text { acre-foot per mile } & 766.3 & \text { cubic meter per kilometer } \\ \text { cubic foot per second } & 28.317 & \text { liter per second }\end{array}$




\title{
CHANNEL INFILTRATION FROM FLOODFLOWS ALONG THE PAWNEE RIVER AND ITS TRIBUTARIES, WEST-CENTRAL KANSAS
}

\author{
By
}

\author{
J.B. Gillespie and C.A. Perry
}

\begin{abstract}
Most of the streams in west-central Kansas are ephemeral or intermittent. Natural recharge to the alluvial aquifers underlying these streams occurs during periods of storm runoff when the ephemeral channels are inundated. Proposed flood-retarding structures within the basin will alter the downstream runoff characteristics in these channels by reducing the peak flow and stage and increasing the flow duration.
\end{abstract}

The infiltration rate on ephemeral streams was determined at five sites within the Pawnee River basin. Infiltration tests were conducted in channel infiltrometers constructed by isolating a small section of channel with two plastic-lined cofferdams. At two of the sites, perched ground-water mounds intersected the bottom of the channel and reduced the infiltration rate. At two other sites where the perched groundwater mounds did not reach the bottom of the channel, the infiltration rate was directly proportional to the stage.

Comparison of infiltration volumes from simulated controlled and uncontrolled floodflows at the five sites indicated an average increase of about 2 percent with the controlled floodflow. Cumulative infiltration volumes for these simulations ranged from 1.2 to 31 percent of the flood volume.

\section{INTRODUCTION}

Most streams in west-central Kansas are ephemeral or intermittent. Natural recharge to the alluvial aquifers underlying these streams occurs during periods of storm runoff when the ephemeral channels and parts of the adjacent flood plain are inundated. The alluvial aquifers underlying many of the smaller tributaries furnish water to stock and domestic wells while the alluvial aquifers underlying the larger tributaries and main stems provide ground water for irrigation, municipal, and industrial uses.

Information concerning channel-infiltration rates, unsaturated and saturated flow, and lithology of the unsaturated zone is needed along the Pawnee River and its tributaries in westcentral Kansas (fig. 1). The purpose of the study described in this report was to estimate at selected sites the infiltration of surface water to the alluvial aquifers underlying the main stem and tributaries of the Pawnee River during controlled and uncontrolled floodflows. The study was conducted during $1985-86$ by the U.S. Geological Survey, in cooperation with the U.S. Soil Conservation Service, Pawnee Watershed District No. 81, and Southwest Kansas Groundwater Management District No. 3.

Infiltration rates were determined at five sites (sites 1 to 5) on ephemeral streams within the Pawnee River basin (fig. 1) by using channel and double-ring infiltrometers. The data are used to estimate the effects on ground-water recharge of controlled releases from proposed flood-retarding structures to be built by the U.S. Soil Conservation Service and the Pawnee Watershed District No. 81. These floodretarding structures will alter the downstream runoff characteristics by reducing the peak flow and stage and increasing the duration of flow, as well as decreasing the sediment loads in the streams. Infiltration to the alluvial aquifers under these modified floodflow conditions may not be the same as that from natural or uncontrolled floodflows and needs to be quantified. These data also are needed by Groundwater Management Districts to more effectively manage their water resources. 


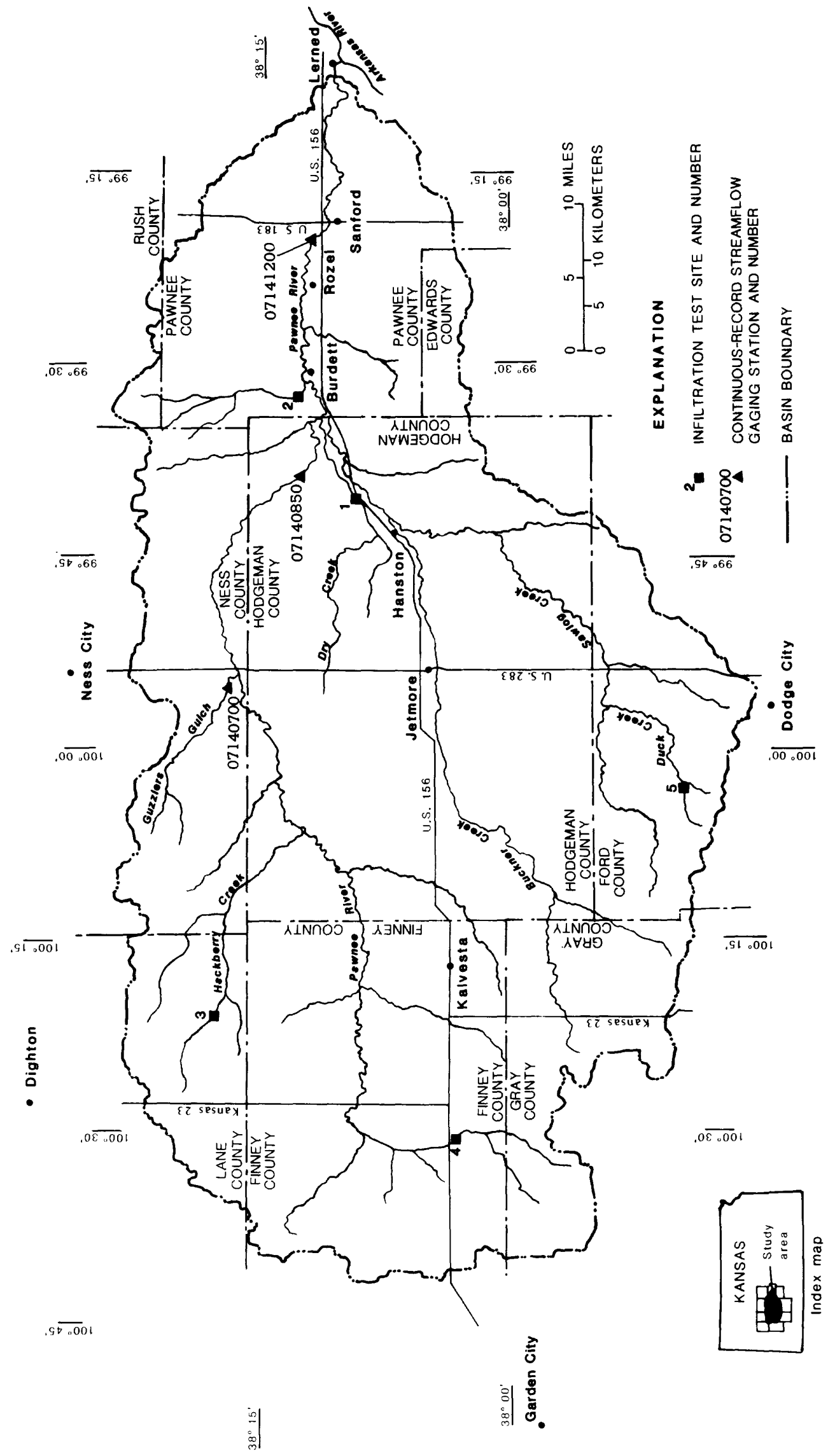

号 


\section{PHYSICAL SETTING}

The Pawnee River basin in west-central Kansas is in both the High Plains and Plains Border sections of the Great Plains physiographic province of the Interior Plains division (Fenneman, 1946) and has a drainage area of about 2,250 square miles. Buckner and Sawlog Creeks are the major tributaries to the Pawnee River. The Pawnee River originates on the High Plains in northern Gray County and follows an easterly course until it joins the Arkansas River at Larned (fig. 1). The Pawnee River and its tributaries have eroded valleys into limestone, sandstone, and shale of Cretaceous age. These valleys contain alluvial aquifers that are recharged by floodflows that occur in the Pawnee River and its tributaries, which are mostly ephemeral or intermittent streams. The downstream reaches of the Pawnee River and its major tributaries were once perennial; however, because of intense irrigation development and subsequent decline in the water table of the major valley aquifers and possibly because of land-treatment practices, there are now few reaches in the Pawnee River basin with perennial flow.

Long-term average annual precipitation, which generally decreases westward across Kansas, ranges from 23.35 inches at Larned at the eastern edge of the Pawnee River basin to 18.76 inches at Garden City, which is located about 10 miles west of the western boundary of the basin (National Oceanic and Atmospheric Administration, 1985). Average annual precipitation values for any particular year can range from one-half to nearly twice these longterm average annual values. Most of the precipitation occurs during the spring and summer months (April through August).

\section{CHANNEL INFILTRA'TION}

Infiltration tests were conducted in channels of the Pawnee River and its tributaries at five sites--(1) Dry Creek near Hanston, (2) unnamed tributary to the Pawnee River near Burdett, (3) Hackberry Creek near Dighton, (4) Pawnee River near Kalvesta, and (5) Duck Creek near Dodge City (fig. 1). The sites were selected to represent different channel types, geomorphology, unsaturated-zone lithology, depth to the water table, and geographical area within the Pawnee River basin. Limited hand augering was conducted at many potential sites. The selected sites are located downstream from proposed flood-retarding structure sites and are on small channels because of size limitations in building the cofferdams for this study. The sites were selected in cooperation with the U.S. Soil Conservation Service, Pawnee Watershed District No. 81, and Southwest Kansas Groundwater Management District No. 3.

An infiltration rate was determined at each site by using the channel-infiltrometer method. A short section of an ephemeral channel was isolated with two cofferdams, creating a channel infiltrometer. Therefore, the infiltration rate determined for these sites represents an integration of the infiltration-rate values of water moving through the bottom and sides or banks of the channel. This test procedure or method more nearly duplicates natural infiltration conditions than would the use of the standard ring-infiltrometer method. Construction details and equipment location of a channel infiltrometer are shown in figures 2 and 3. Wooden cofferdams were used at each site except site 2 where earthen cofferdams were constructed because of a greater depth of water in the channel infiltrometer.

The rising and falling stages of a streamflow hydrograph were simulated by letting water into or out of the ponded reach of channel created by the two cofferdams. The hydrographs simulated uncontrolled floodflows and floodflows that were affected or controlled by flood-retarding structures. The water was discharged into the channel infiltrometer either by pumping or by gravity flow from a storage tank at approximately 1 -foot stage increments every 20 to 30 minutes to simulate the initial rising stage of the streamflow hydrograph. This procedure allowed time to measure an infiltration rate for each stage increment. The water level in the channel infiltrometer was measured by a continuous graphical recorder activated by a float in a 10-inch diameter stilling well.

The infiltration rate was calculated from the decline in the water level in the channel infiltrometer during the 20 - to 30 -minute period between the time of the incremental fillings. The infiltration rate calculated by this method represents the integrated or average infiltration 


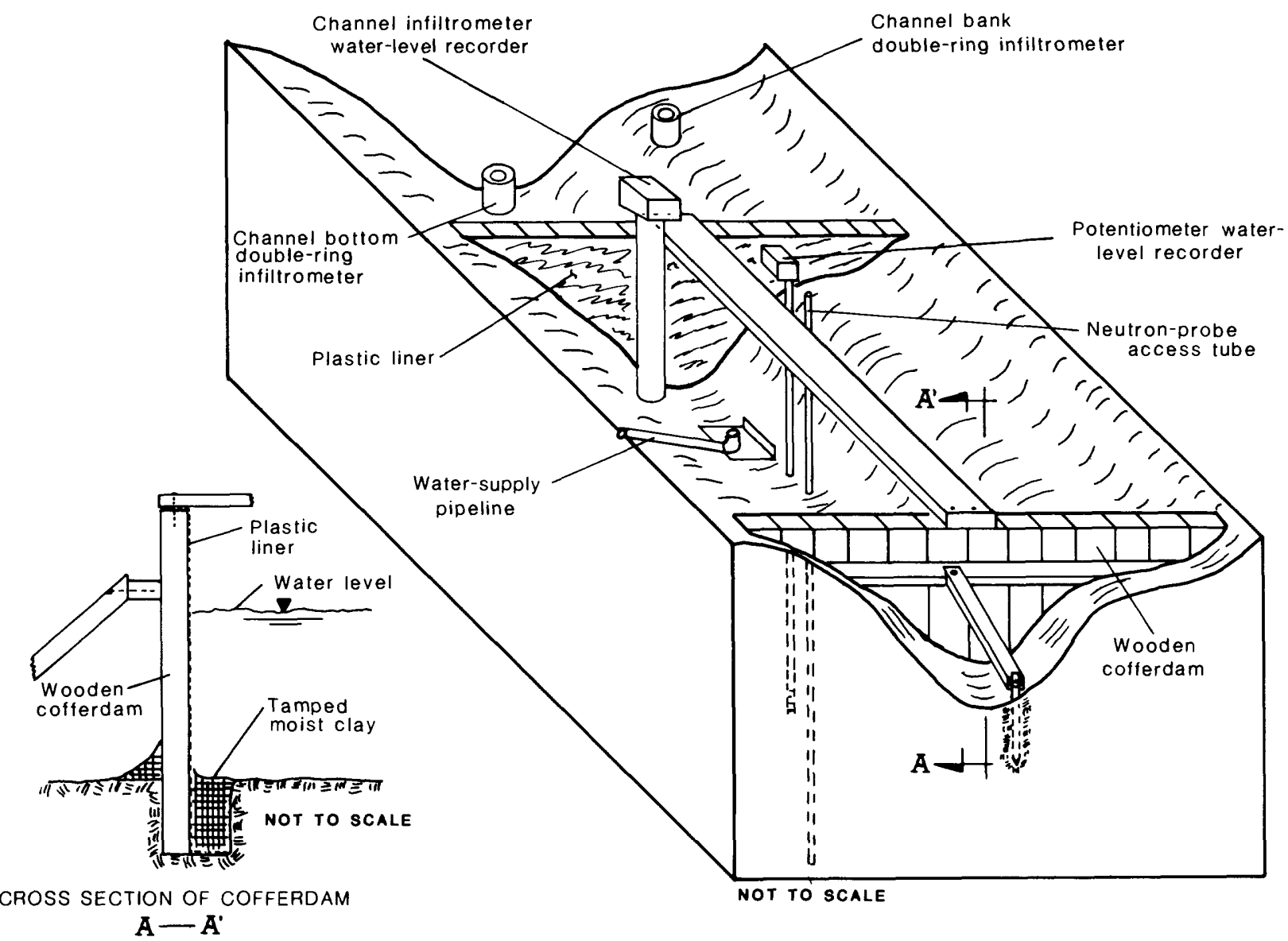

Figure 2. Construction details of channel infiltrometer and location of monitoring equipment.

through the bottom and sides of the channel; that is, the wetted perimeter. The stage or water level in the channel infiltrometer was measured continuously. The infiltration rate was calculated at varying stages by determining the water-level decline during an increment of 30 minutes to several hours, and therefore the infiltration rate equals the change in water level divided by the time increment.

Infiltration-rate curves were developed for infiltration rate as a function of time and stage at specific stage increments. The infiltration rate was estimated by using clear water from wells that was relatively sediment free except for some initial murkiness during the filling of the channel infiltrometer; therefore, these infiltration rates may be larger than for natural floodflows. Ground-water-recharge rates probably will be less than these infiltration rates because some of the infiltrated water will be lost to evapotranspiration and soil retention. Also, because of the time taken to fill the channel infiltrometers, it was not possible to calculate the early infiltration-rate values for the initial wetting of the channel. These values probably were much greater, but because they were of short duration, being less than 5 to 10 minutes, the total volume of infiltration was not considered significant. 


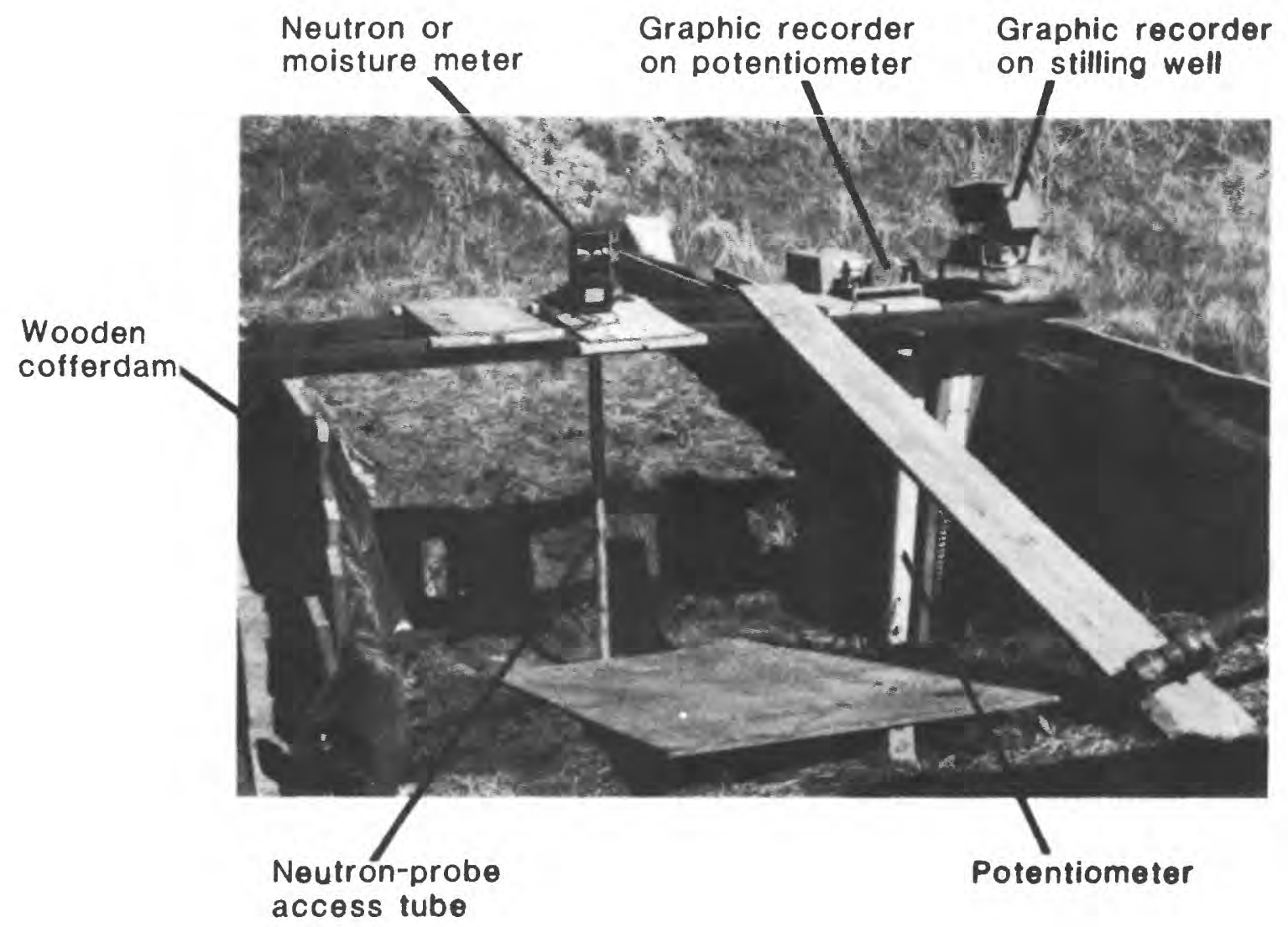

Figure 3. Channel infiltrometer and monitoring equipment at site 3 .

A hole was augered near the edge of the channel at each site, from which a gamma log was obtained (fig. 4). A gamma log shows the natural gamma radiation of the alluvium. In general, the gamma-ray activity increases with the increase in clay content of the alluvium. A lithologic log was prepared from the auger cuttings and the gamma log (fig. 4).

Potentiometers were installed within the channel infiltrometers above clay layers in the unsaturated zone or the water table and used to monitor any perching above the clay or restricting layers, or ground-water mound buildup on the water table. The potentiometers were constructed by augering a 4 -inch diameter hole and inserting a 2-inch steel or polyvinylchloride pipe having an open end and about 6 inches of perforations. The annular space outside the pipe was backfilled with coarse sand for about 1 foot and with bentonite to the land surface.
A neutron-moisture-probe access tube was installed in the unsaturated zone to monitor changes in moisture content, in percent by volume, and movement of the wetting front through the unsaturated zone. The access tube was installed by driving 2-inch diameter steel tubing down a 2-inch augered hole to ensure a watertight fit. The tubing was plugged at the bottom end to prevent any entry of water. The neutron probe contains a source that emits highenergy, fast neutrons and a detector that measures rebounding low-energy, slow neutrons. Because fast neutrons are slowed substantially by collision with the hydrogen nuclei in water, the number of slow neutrons that strike the detector is proportional to the moisture content of the alluvium. As the probe was raised from the bottom of the access tube, readings were made at $\mathbf{0 . 5}$-foot increments, and a log was made of the moisture content within an assumed radius of about 0.5 foot from the 


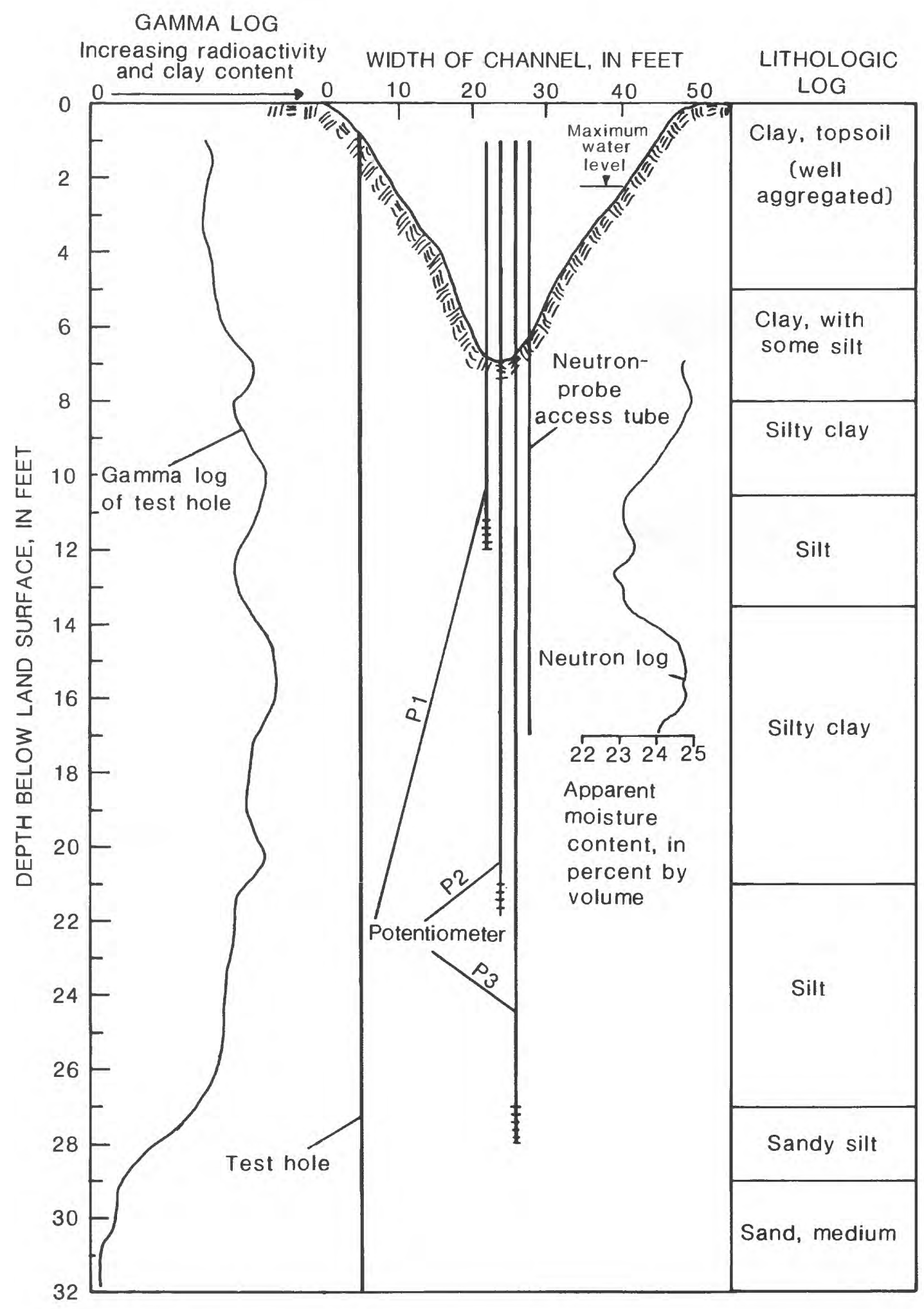

Figure 4. Gamma, neutron, and lithologic logs, channel configuration, and location of test hole, potentiometers, and neutron-probe access tube at site 1 . 
tube. From a comparison of the neutron logs made before and during the infiltration tests, change in moisture content was calculated.

In this report, the term "apparent moisture content" is used to describe the moisture profile at each site. As the neutron-moisture-probe access holes were augered, soil samples were collected, but moisture content by weight was not calculated, and no density log was made for the access hole. To determine the moisture content of the soil profile at the sites, the readings from the neutron-moisture measurements were used in a computer program that had been developed and calibrated for a natural recharge site in an adjacent county at which neutron-moisture data were collected in the same manner (Sophocleous and Perry, 1987). It was assumed that the apparent moisture content was near the actual moisture content; however, the change in moisture content during the infiltration tests was a major interest in this study.

Double-ring infiltrometers were placed in the bottom and in the bank of the channel near the channel infiltrometer for comparison of the different methods for measuring infiltration rates (Bouwer, 1962). The outer ring was 22 inches in diameter, and the inner ring was 8 inches. Both were driven into the soil about 1 foot. A constant water level of 2 feet was maintained in the double-ring infiltrometer in the bottom of the channel, and a water level of 1 foot was maintained in the double-ring infiltrometer in the bank. The infiltration rate was calculated from water-level changes in the water-supply barrels, which were measured continuously by a float-activated recorder. The infiltration measurements were conducted in the late fall and early spring to minimize the effects of evapotranspiration.

\section{Dry Creek Near Hanston}

\section{Site Description}

Site 1 on Dry Creek is in the SE1/4 NW1/4 NW1/4 sec. 7, T. 22 S., R. 21 W., near Hanston in Hodgeman County, on land owned by Gordon Parr. The area of the drainage basin upstream from the site is 74.1 square miles. Dry Creek's ephemeral channel is incised into the broad flood plain of Buckner Creek valley and is about 50 feet wide and 7 feet deep (fig. 4). The valley alluvium is about 100 feet thick at this location and consists of fluvial clay and silt in the upper 29 feet, underlain by mainly sand and gravel (fig. 4). The water table is about 29 feet below the bottom of the channel. The apparent moisture content by volume of the silt and clay below the bottom of the channel before the infiltration tests ranged from about 23 to 25 percent, which was close to saturation (fig. 4).

The channel infiltrometer was constructed by placing two wooden cofferdams 15 feet apart across the channel of Dry Creek. Three 2-inch diameter potentiometers (P1, P2, P3) were installed below the bottom of the channel; P1 at 5 feet, just above a silty clay layer; P2 at 15 feet, at the bottom of the silty clay layer; and P3 at 21 feet, just above the sand layer (fig. 4). The water level in P1 was recorded continuously by a recorder driven by an electrical water-surface follower. The water level in P2 and P3 was measured manually with a steel tape. A neutron-probe access tube was installed in an access hole hand augered to 10 feet below the bottom of the channel. The water level in the channel infiltrometer was measured by a continuous graphical recorder connected to a float in a 10-inch diameter stilling well.

\section{Infiltration Tests}

Infiltration test 1 at site 1 started at 1220 hours on November 5,1985 , to simulate recharge during an uncontrolled floodflow or peak. Ground water was pumped into the channel infiltrometer from an irrigation well about 500 feet west of site 1 . The channel infiltrometer was filled with water in the manner previously described to a depth of 4.8 feet (fig. 5). Initially, the plan was to fill to a depth of 6 feet; however, a small leak occurred in one of the cofferdams, and the filling of the channel infiltrometer was stopped to prevent any more leakage. The water level then was lowered to 4.8 feet by pumping. From that point the water level declined because of infiltration of the water through the wetted perimeter of the channel infiltrometer. Test 1 continued for 107 hours (fig. 5). The water level in $\mathrm{P} 1$ rose until it reached the bottom of the channel about 32 hours after the start of test 1 (fig. 5). During test 


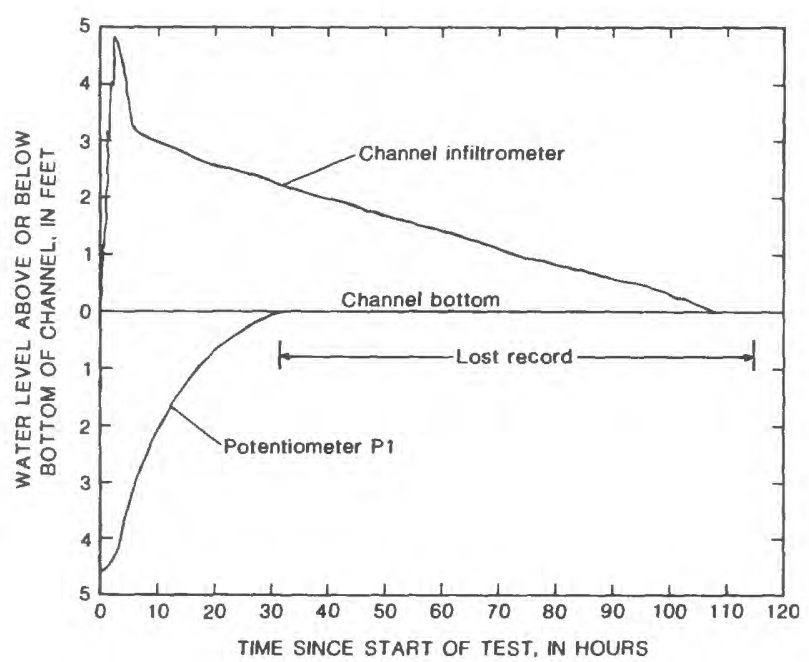

Figure 5. Water level in channel infiltrometer and shallow potentiometer during test 1 at site 1 .

1, no water was detected in P2 or P3. Apparently there was temporary perching of percolating water above the silty clay layer about 6 feet below the bottom of the channel.

The change in apparent moisture content during test 1 is shown in figure 6 . At 200 hours after the start of the test 1 much of the soil column was near saturation. Each soil type has a different moisture content at which it becomes saturated. Saturation moisture can be determined only by detailed soil analyses. The small apparent change in moisture content probably is due to initial soil conditions being close to saturation. This condition was caused by irrigation tailwater in the channel about 1 month before test 1 .

Infiltration-rate values were calculated using the channel-infiltrometer method previously described and were plotted as a function of the stage and time since test 1 started (fig. 7). The infiltration-rate values initially were rapid with the higher stage producing the more rapid rate. Values are rapid initially because water is moving into and through cracks, root tubes, earthworm holes, and other macropores in the soil. As these pores fill up, the soil particles start swelling after wetting, and entrapped air decreases the permeability of the soil. Therefore, the infiltration rate starts decreasing. After 7 hours since the start of test 1 , the infiltration rate for all the different stages decreased to about 1.0

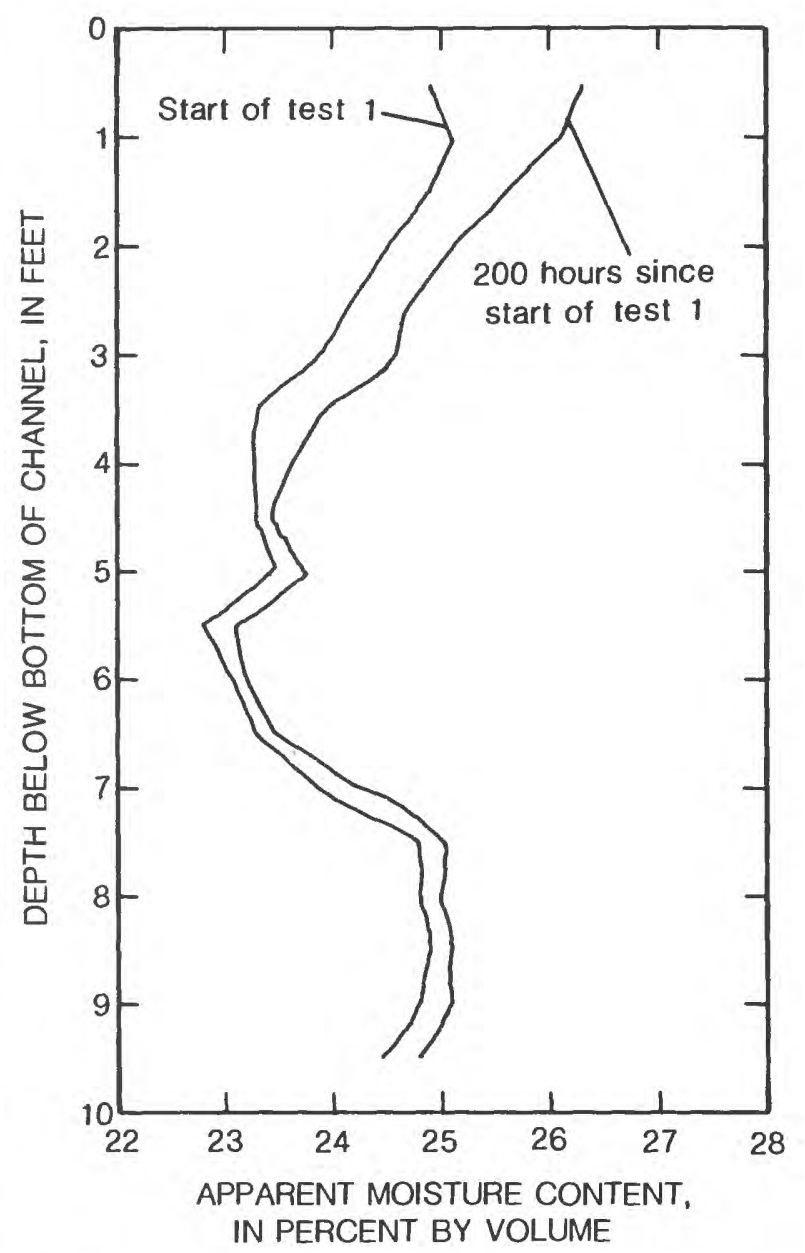

Figure 6. Neutron logs from neutron-probe access tube at site 1.

foot per day (fig. 7). The infiltration rate probably decreased because the ground-water mound caused by the temporary perching of the percolating water above the silty clay layers at about 1 foot and 6 feet below the bottom of the channel reached the bottom of the channel.

Infiltration test 2 started at 1100 hours on November 20,1985, to simulate recharge during a controlled floodflow or peak whose stage was about two-thirds of the uncontrolled peak simulated during test 1 . Ground water was pumped into the channel infiltrometer from the same source as test 1 . The channel infiltrometer was filled with water in the manner previously described to a depth of 3.1 feet (fig. 8). The water level was allowed repeatedly to decline about 0.5 foot before being raised again to about 3 feet. After 6 days, the continuous filling was discontinued, and the water level declined as the water infiltrated through the wetted perimeter 
of the channel infiltrometer. Test 2 continued for 244 hours (fig. 8). The water level in $\mathrm{P} 1$ rose until it was about 1.1 feet above the bottom of the channel (fig. 8).

Initial infiltration rates during test 2 decreased rapidly to a relatively constant 0.9 foot per day (fig. 8). The silty clay layer about 1 foot below the bottom of the channel is probably restricting infiltration.

Double-ring infiltrometers were placed in the bottom and in the bank of the channel as previously described. Comparison of infiltration-rate values from the channel and double-ring infiltrometers (fig. 9) was poor. The rapid infiltration rate of about 32 to 58 feet per day for the double-ring infiltrometers probably was caused by flow from the relatively small area of the rings into macropores in the soil at the bottom and banks of the channel. The rate and volume of water moving downward from the infiltrometers were not large enough to cause any temporary perched mounding that would affect the infiltration rates.

\section{Unnamed Tributary Near Burdett}

\section{Site Description}

Site 2 (on an unnamed tributary of the Pawnee River) is in the SW1/4 NE1/4 NW1/4 sec. 20, T. 21 S.,R. 20 W., near Burdett in Pawnee County, on land owned by Donald Nuckolls. The area of the drainage basin upstream from the site is 39.7 square miles. The unnamed tributary's ephemeral channel is incised into the broad flood plain of the Pawnee River valley and is about 140 feet wide and about 8 feet deep (fig. 10). The valley alluvium is about 90 feet thick and consists of fluvial clay and silt in the upper 31 feet and mostly mediumto-coarse sand and gravel in the lower 59 feet (fig. 10). The water table is about 30 feet below the bottom of the channel. The apparent moisture content before the infiltration test ranged from about 19 to 23 percent (fig. 10).

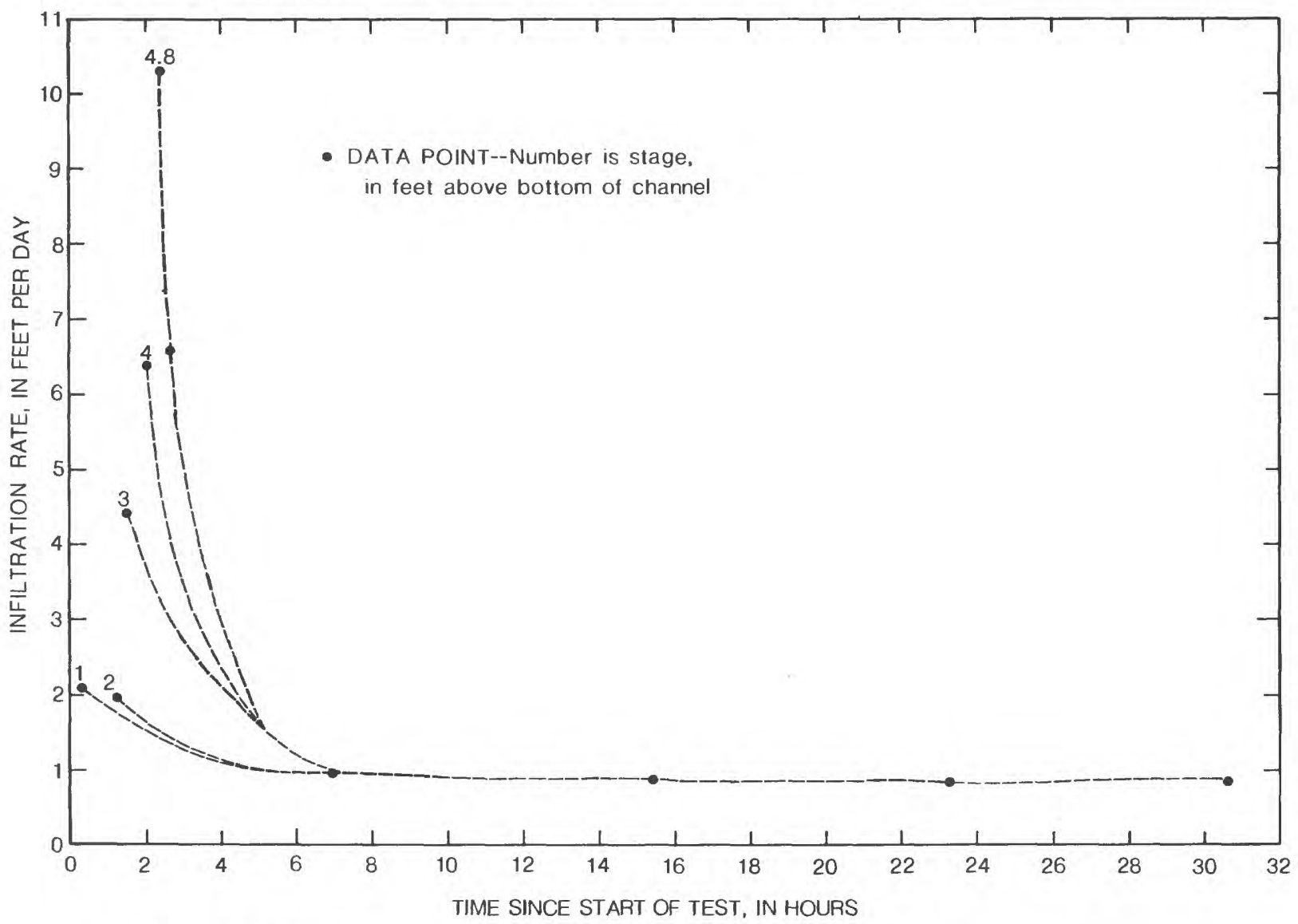

Figure 7. Infiltration rate as a function of stage and time in chanel infiltrometer during test 1 at site 1. 

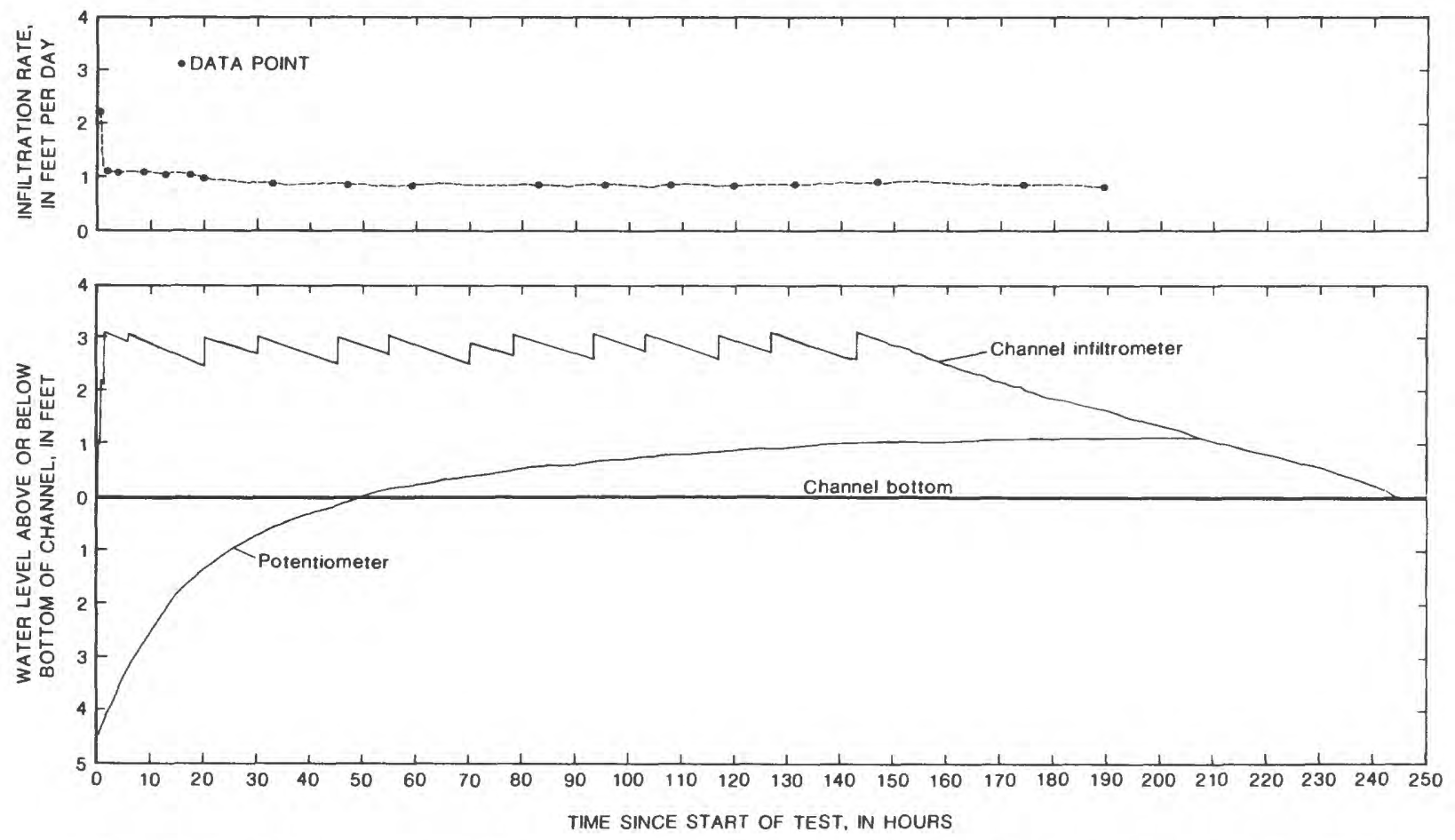

Figure 8. Water level in channel infiltrometer and shallow potentiometer and infiltration rate during test 2 at site 1.

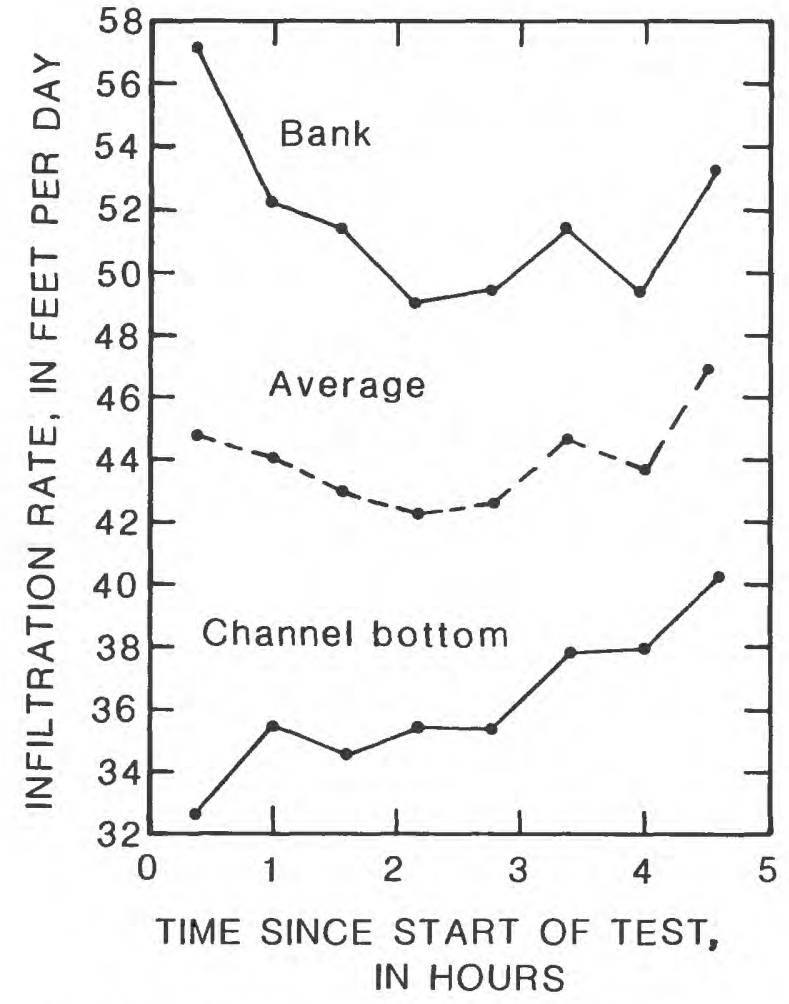

Figure 9. Infiltration rate for double-ring infiltrometers at site 1 .
The channel infiltrometer was installed by constructing two earthen cofferdams with a bulldozer about 50 feet apart across the channel of the unnamed tributary and lining the inside slopes of the cofferdams with sheet plastic (fig. 11). A 4-inch diameter potentiometer (P1) was installed at 5.5 feet below the bottom of the channel just above a clay layer (fig. 10). The water level in P1 was recorded continuously by a float-activated recorder. A neutron-probe access tube was installed in a hole hand augered to 14 feet below the bottom of the channel (fig. 10). The bottom of the neutron-probe access tube was kept unplugged so that it could be used as a potentiometer (P2) at 14 feet below the bottom of the channel. The water level in P2 was measured manually with a steel tape. The water level in the channel infiltrometer was measured by a continuous float-activated graphical recorder in a 10-inch diameter stilling well.

\section{Infiltration Test}

Infiltration test 1 at site 2 started at 1115 hours on March 21, 1986, to simulate recharge during an uncontrolled floodflow. Ground water was pumped into the channel infiltrometer from 


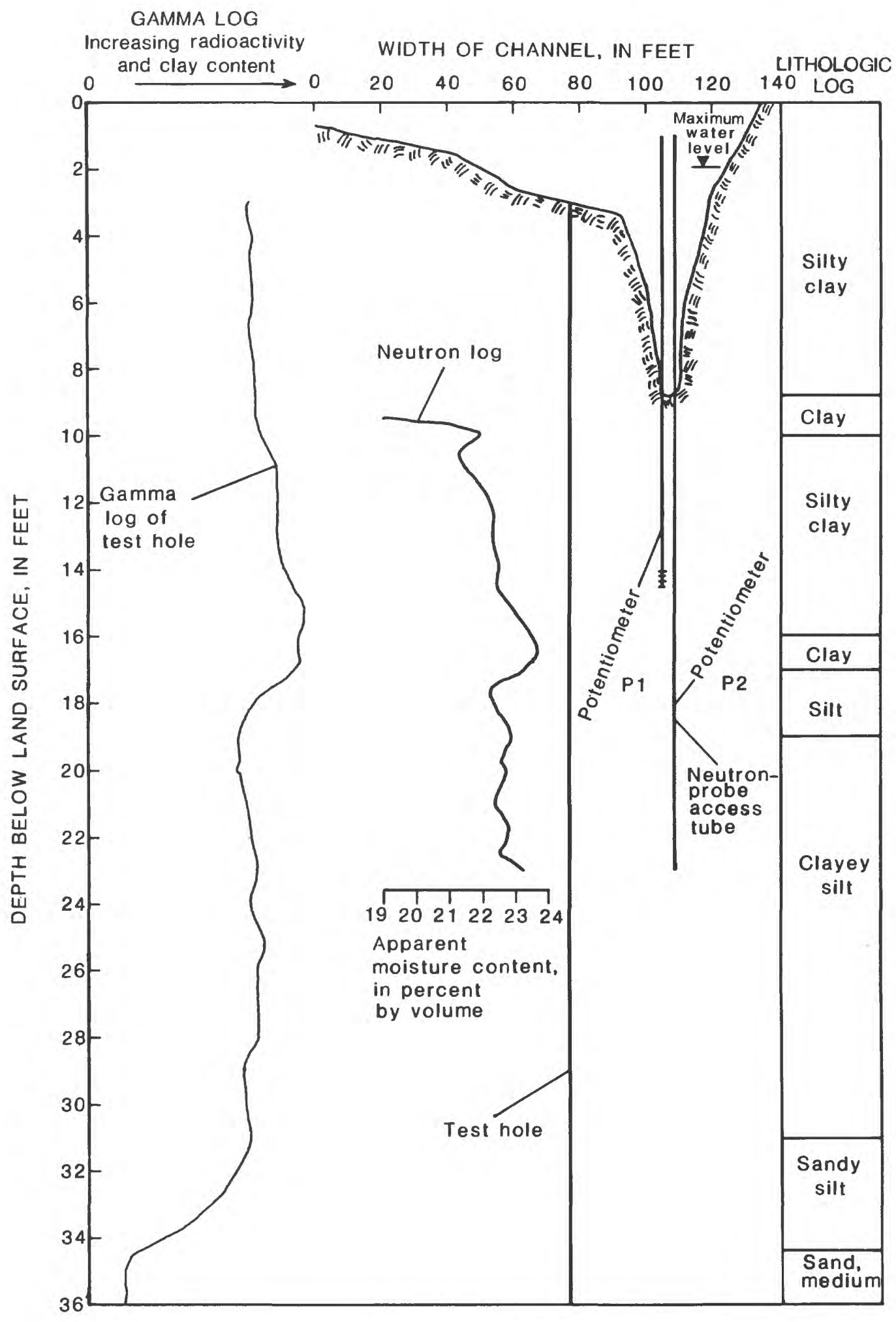

Figure 10. Gamma, neutron, and lithologic logs, channel configuration, and location of test hole, potentiometers, and neutron-probe access tube at site 2. 


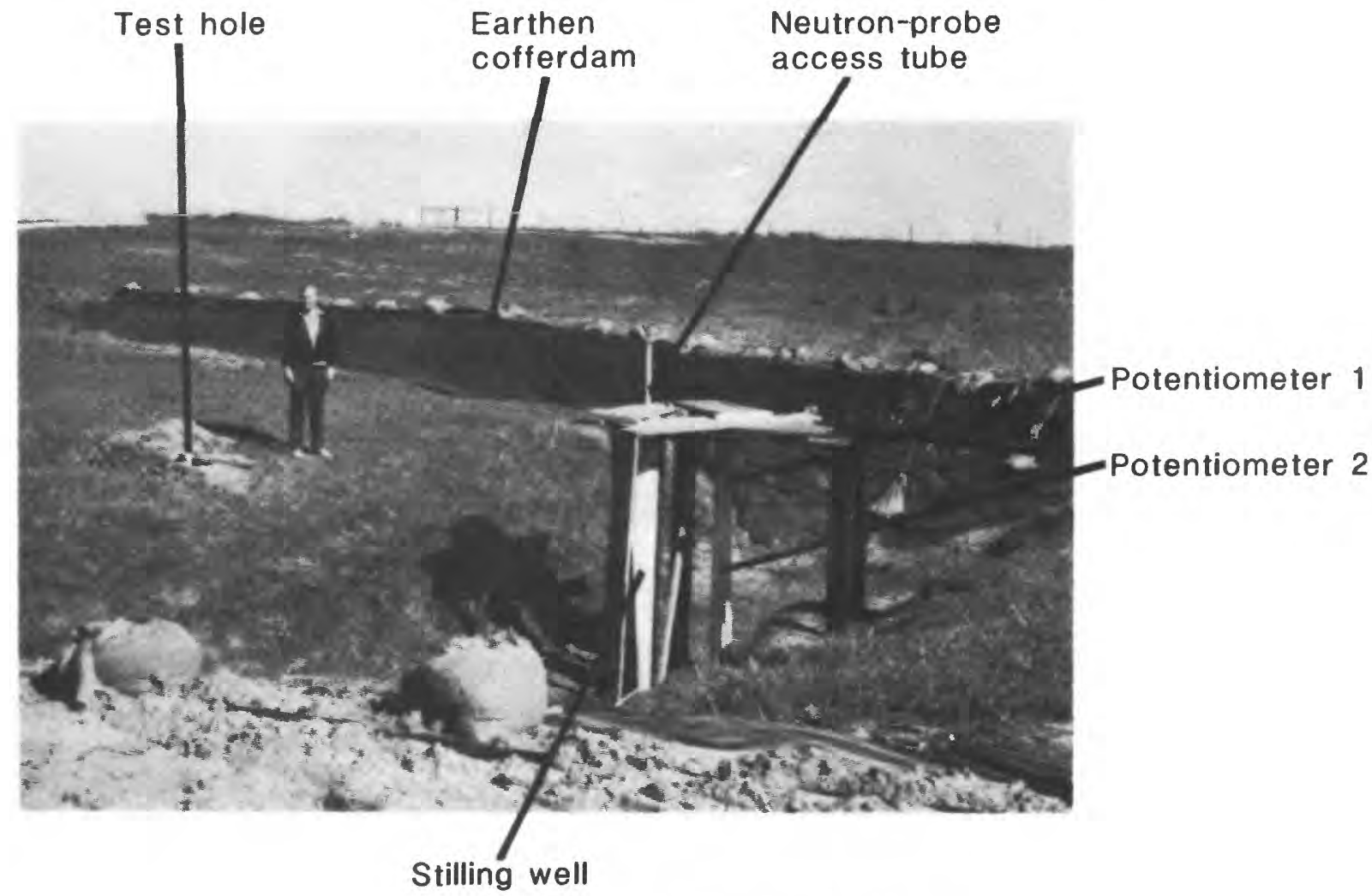

Figure 11. Channel infiltrometer at site 2.

an irrigation well about 1,000 feet east of the site. The channel infiltrometer was filled in incremental stages with water in the manner previously described to a depth of 6.8 feet (fig. 12). From that point the water level declined due to the infiltration of water through the wetted perimeter of the channel infiltrometer. Test 1 continued for 11 days (fig. 12). The water level in $\mathrm{P} 1$ began rising almost immediately, reaching the bottom of the channel after 5 hours and a maximum height of 5 feet above the bottom after 16 hours. The water level in P1 then declined as the water level in the channel infiltrometer declined (fig. 12). No water was detected in P2 during test 1. An apparent moisture-content change of about 1 percent by volume occurred during test 1 (fig. 13).

The infiltration rate was calculated using the channel-infiltrometer method previously described and was plotted as a function of time since test 1 started (fig. 12). The initial infiltration rate decreased rapidly to a relatively constant rate of less than 1 foot per day. The clay layers at about 1 and 8 feet below the bottom of the channel were probably restricting the flow. Also, the bottom and upper banks of the channel had been puddled or compacted by cattle during the period just prior to test 1 . A second test was not conducted because during test 1 the infiltration rate was slow and there was no apparent infiltration-rate difference as related to varying stage.

Double-ring infiltrometers were placed in the bottom and in the bank of the channel. Comparison of infiltration-rate values from channel and double-ring infiltrometers (fig. 14) was good for the first 5 hours of test 1 . Unlike site 1, the apparent compaction of the soil surface by cattle created a situation where the average soil properties, especially the number and size of the macropores, of the channel infiltrometer and the double-ring infiltrometers were very similar.

\section{Hackberry Creek Near Dighton}

\section{Site Description}

Site 3 on Hackberry Creek is in the SW1/4 SW1/4 NW1/4 sec. 19, T. 20 S., R. 27 W., near 

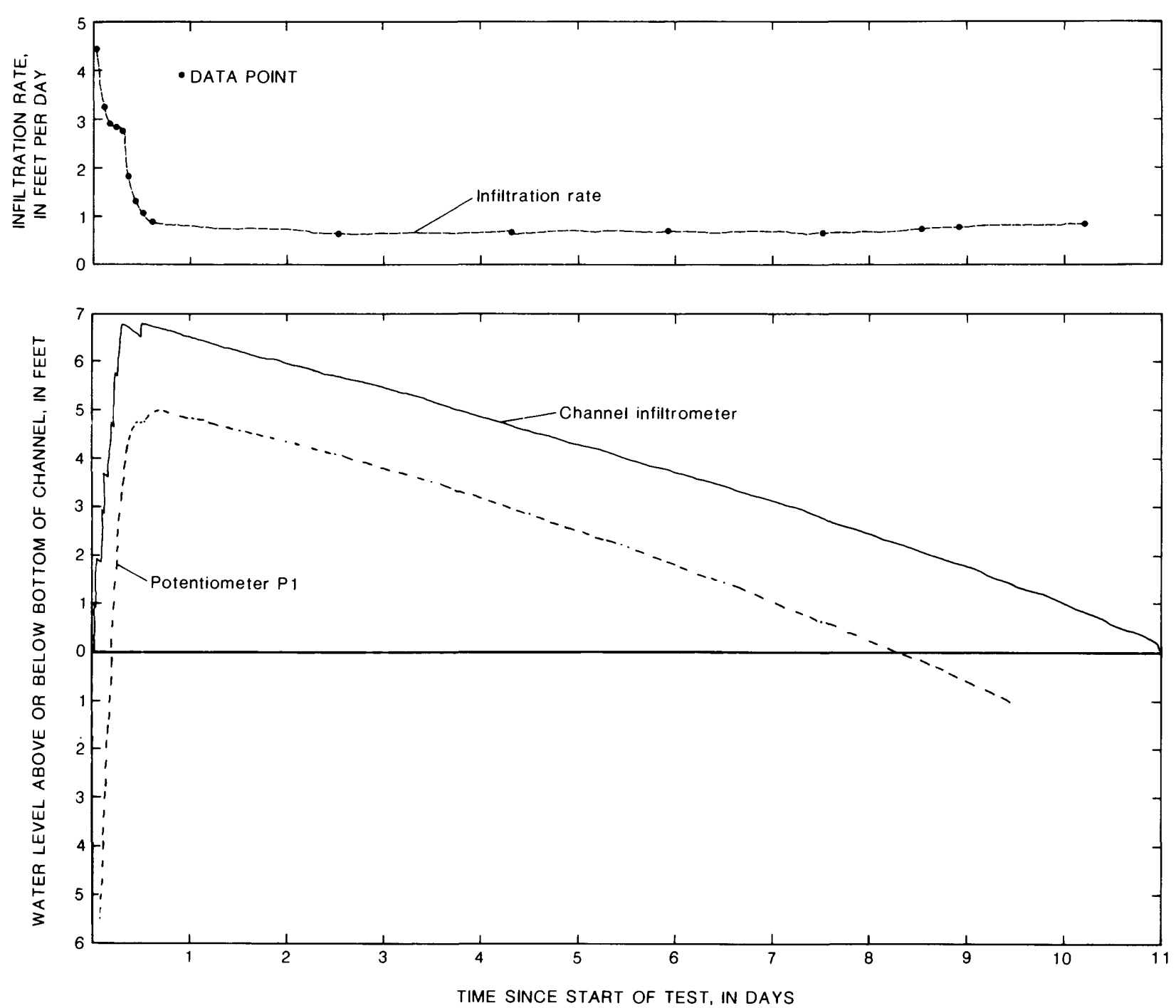

Figure 12. Water level in channel infiltrometer and shallow potentiometer and infiltration rate during test 1 at site 2.

Dighton in Lane County, on land owned by Francis Heath. The area of the drainage basin upstream from the site is 42.8 square miles. Hackberry Creek's ephemeral channel is incised into the narrow flood plain of Hackberry Creek valley and is about 30 feet wide and about 4.5 feet deep (fig. 15). The valley alluvium is about 21 feet thick and consists of fluvial silt and clay, with some sand overlying a weathered chalky limestone (fig. 15). The water table is about 10 feet below the bottom of the channel. The apparent moisture content of the alluvium below the bottom of the channel before the infiltration test ranged from about 20 to 23 percent (fig. 15).

The channel infiltrometer was constructed by placing two wooden cofferdams 12 feet apart across the channel of Hackberry Creek. One 4inch diameter potentiometer (P1) was installed at 5 feet below the bottom of the channel just above a sandy silt layer (fig. 15). The water level in P1 was recorded continuously by a floatactivated graphical recorder. A neutron-probe access tube was installed in an access hole hand augered to 9 feet below the bottom of the channel (fig. 15). The bottom of the neutron-probe access tube was kept unplugged so that it could be used as a potentiometer (P2). The water level in P2 was measured manually with a steel tape. The water level in the channel infiltrometer was measured by a continuous float-activated graphical recorder in a 10 -inch diameter stilling well. 


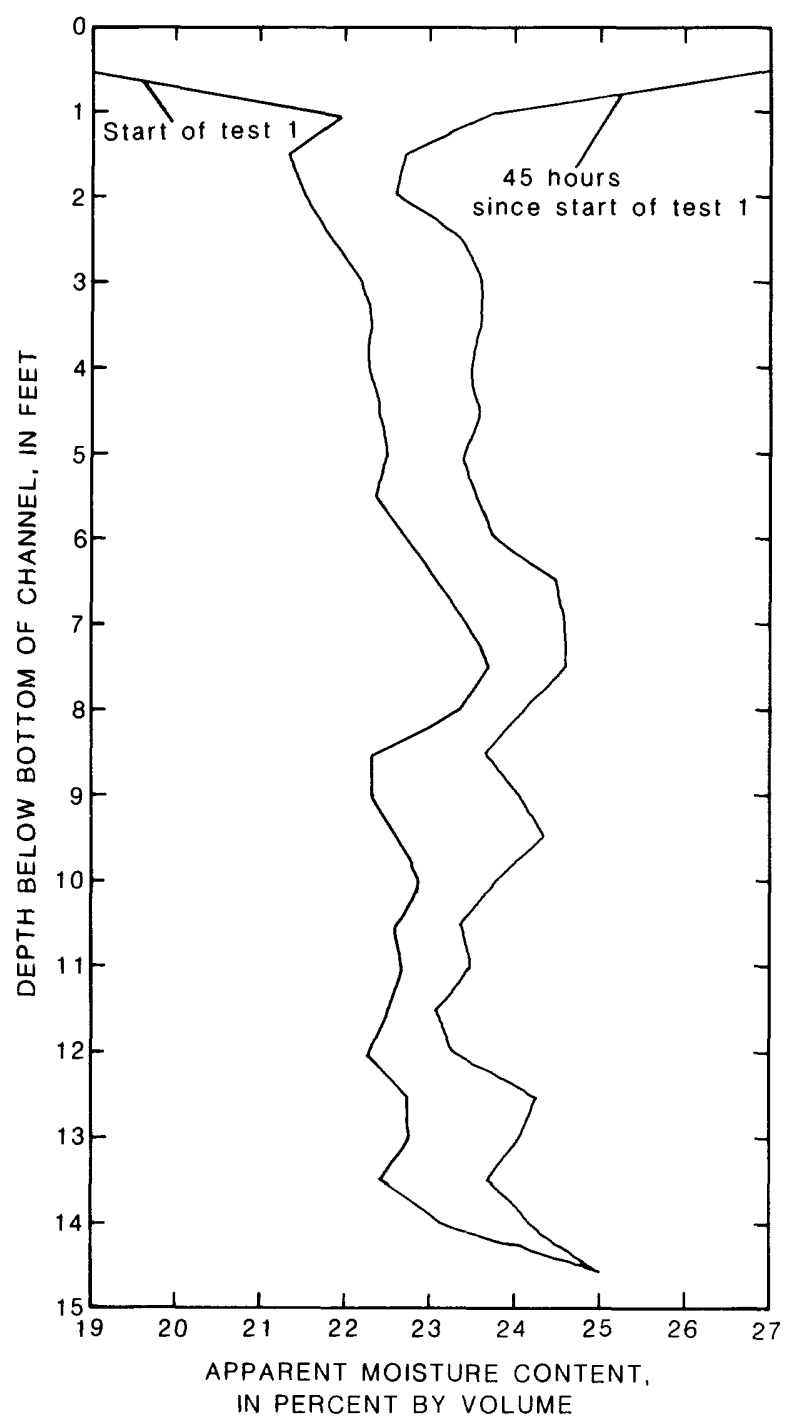

Figure 13. Neutron logs from neutron-probe access tube at site 2.

\section{Infiltration Tests}

Infiltration test 1 at site 3 started at 1430 hours on April 24, 1986, to simulate recharge during an uncontrolled floodflow or peak. Water was discharged into the channel infiltrometer by gravity flow from a 8,400-gallon steel storage tank that was placed temporarily nearby for the infiltration tests. Ground water was hauled by a tank truck to the storage tank from a stock well about 2,000 feet northwest of site 3 . The channel infiltrometer was filled as previously described to a depth of 3.8 feet (fig. 16). Test 1 continued for 42 hours (fig. 16). The water level in P1 rose to within 1.3 feet, but never reached, the bottom

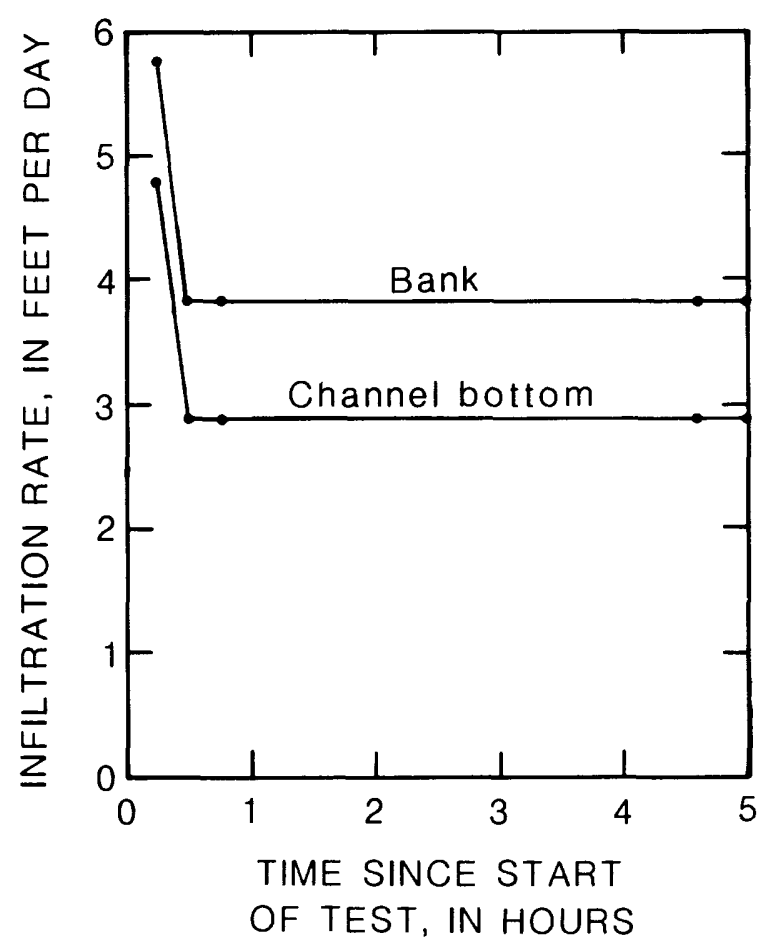

Figure 14. Infiltration for double-ring infiltrometers at site 2.

of the channel. The fluctuation of the water level in P1 corresponded to the varying stage in the channel infiltrometer, thus a varying infiltration rate. No water was detected in $\mathrm{P} 2$ during test 1 . An apparent moisture-content change of about 2 percent occurred during the test (fig. 17). Figure 17 also indicates the progression of the wetting of the alluvium below the bottom of the channel.

The infiltration rate was calculated by using the channel-infiltrometer method previously described and was plotted as a function of the stage and time since the start of test 1 (fig. 18). The calculated infiltration rate ranged from less than 1 to 24 feet per day. The infiltration rate initially was rapid, with the higher stages producing the more rapid rate. As the infiltration rate decreased with time, it was still influenced by stage. Because the temporarily perched ground-water mound does not intersect the bottom of the channel, the hydraulic conductivity of the channel bed material probably is controlling the infiltration rate.

Infiltration test 2 started at 0900 hours on April 26, 1986, to simulate recharge during a controlled floodflow. Water was discharged into 


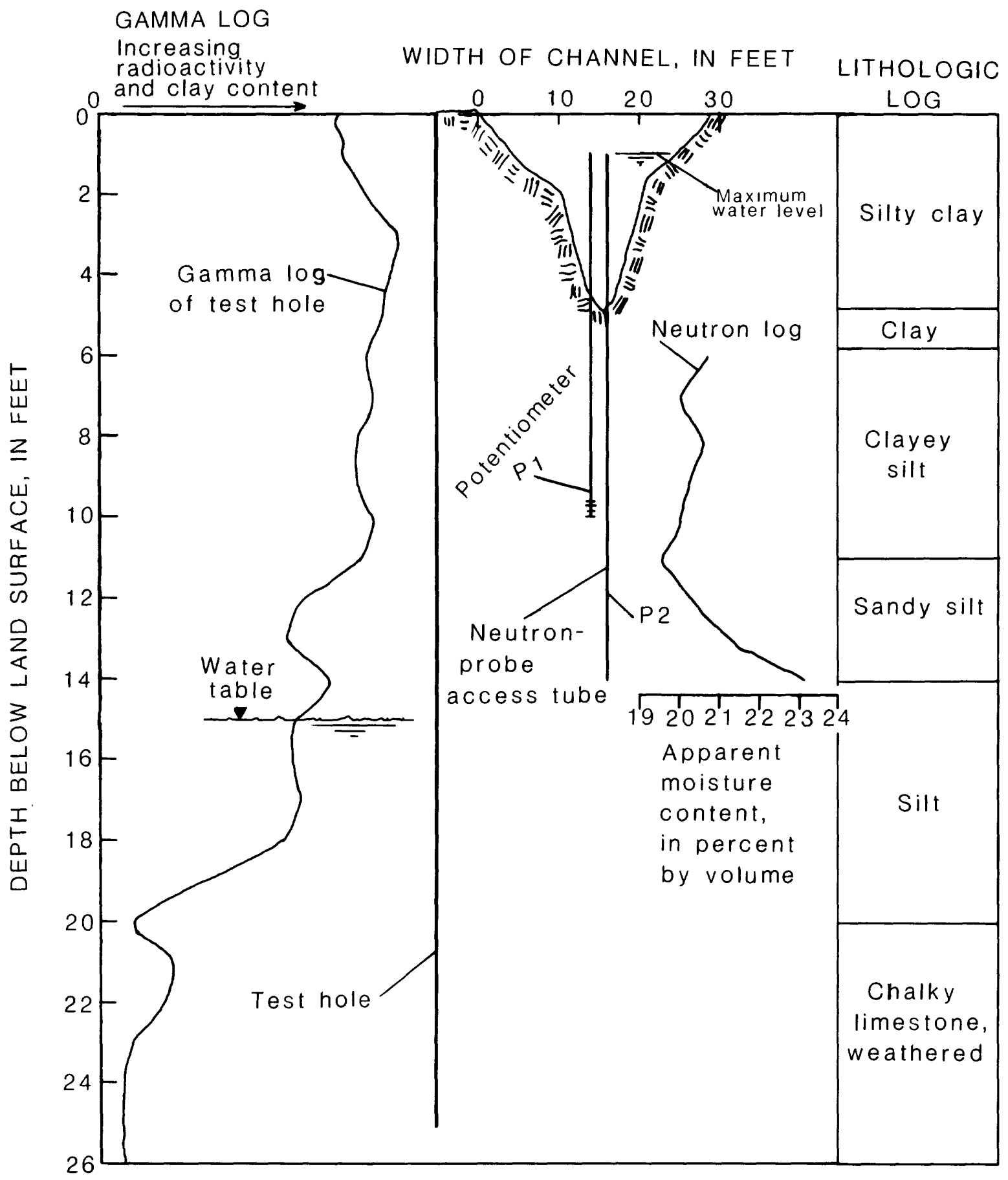

Figure 15. Gamma, neutron, and lithologic logs, channel configuration, and location of test hole, potentiometers, and neutron-probe access tube at site 3 . 


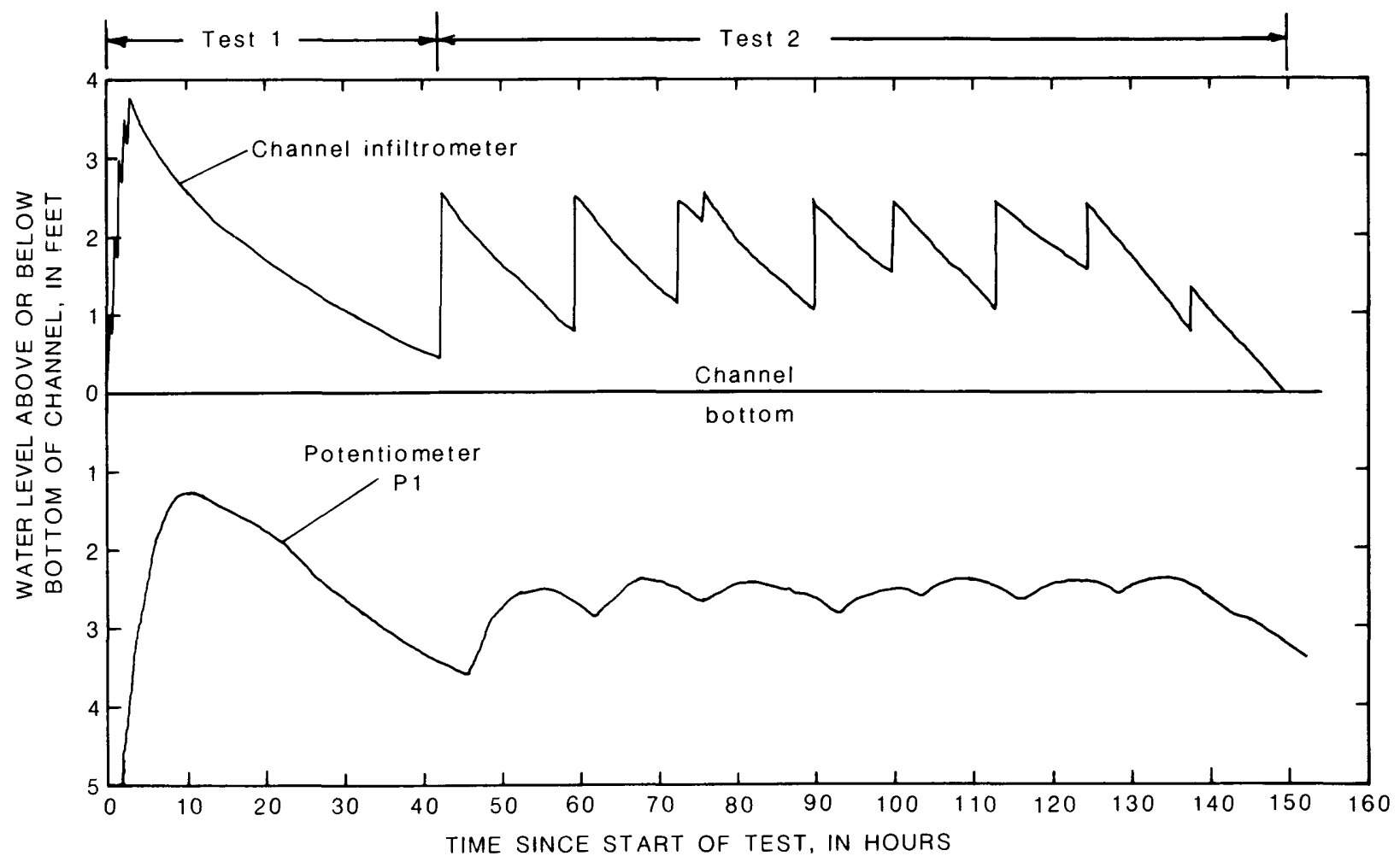

Figure 16. Water level in channel infiltrometer and shallow potentiometer during tests 1 and 2 at site 3 .

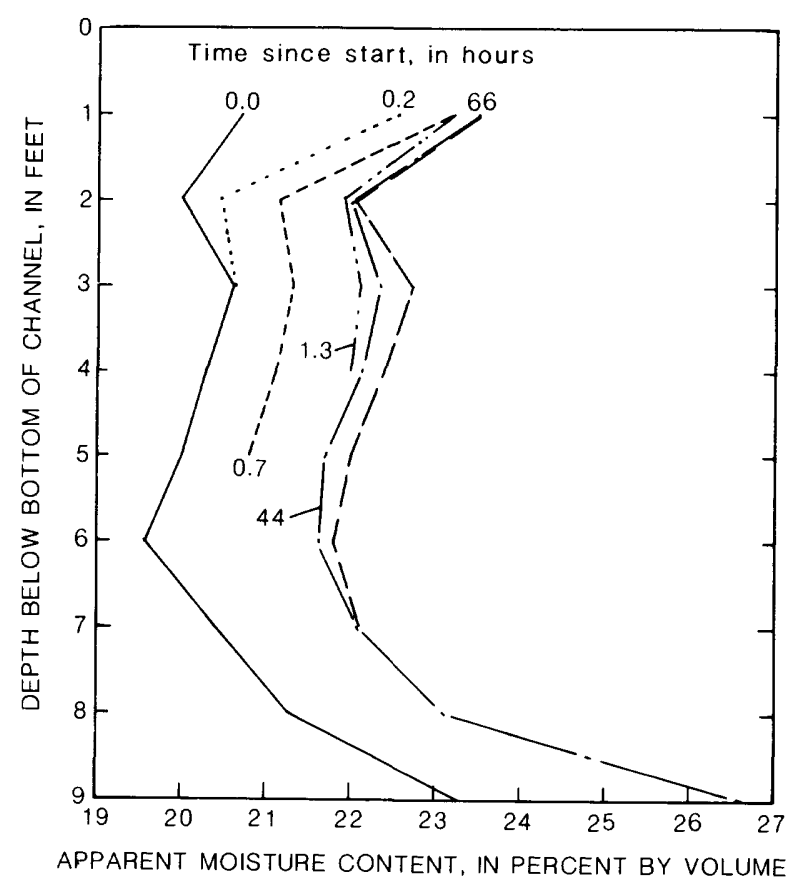

Figure 17. Neutron logs from neutron-probe access tube at site 3. the channel infiltrometer from the same source as test 1 . The channel infiltrometer was filled to a depth of 2.5 feet (fig. 16). The water level was allowed to decline and was raised again to 2.5 feet periodically for 96 hours. Test 2 continued for 108 hours. The water level in P1 did not reach the bottom of the channel, and no water was detected in P2. The infiltration rate was plotted as a function of stage and time since the start of test 2 (fig. 19). For the same stages, the infiltration rate was more rapid and increased during test 2 as compared to during test 1 . The more rapid rate probably was caused by a decrease in the amount of air that was entrapped in the soil, and as the entrapped air escaped or was taken into solution by the percolating water, the hydraulic conductivity of the soil increased, resulting in a more rapid infiltration rate.

Double-ring infiltrometers were placed in the bottom and in the bank of the channel as previously described. Comparison of infiltration-rate values from the channel and double-ring infiltrometers (fig. 20) was fair. As 


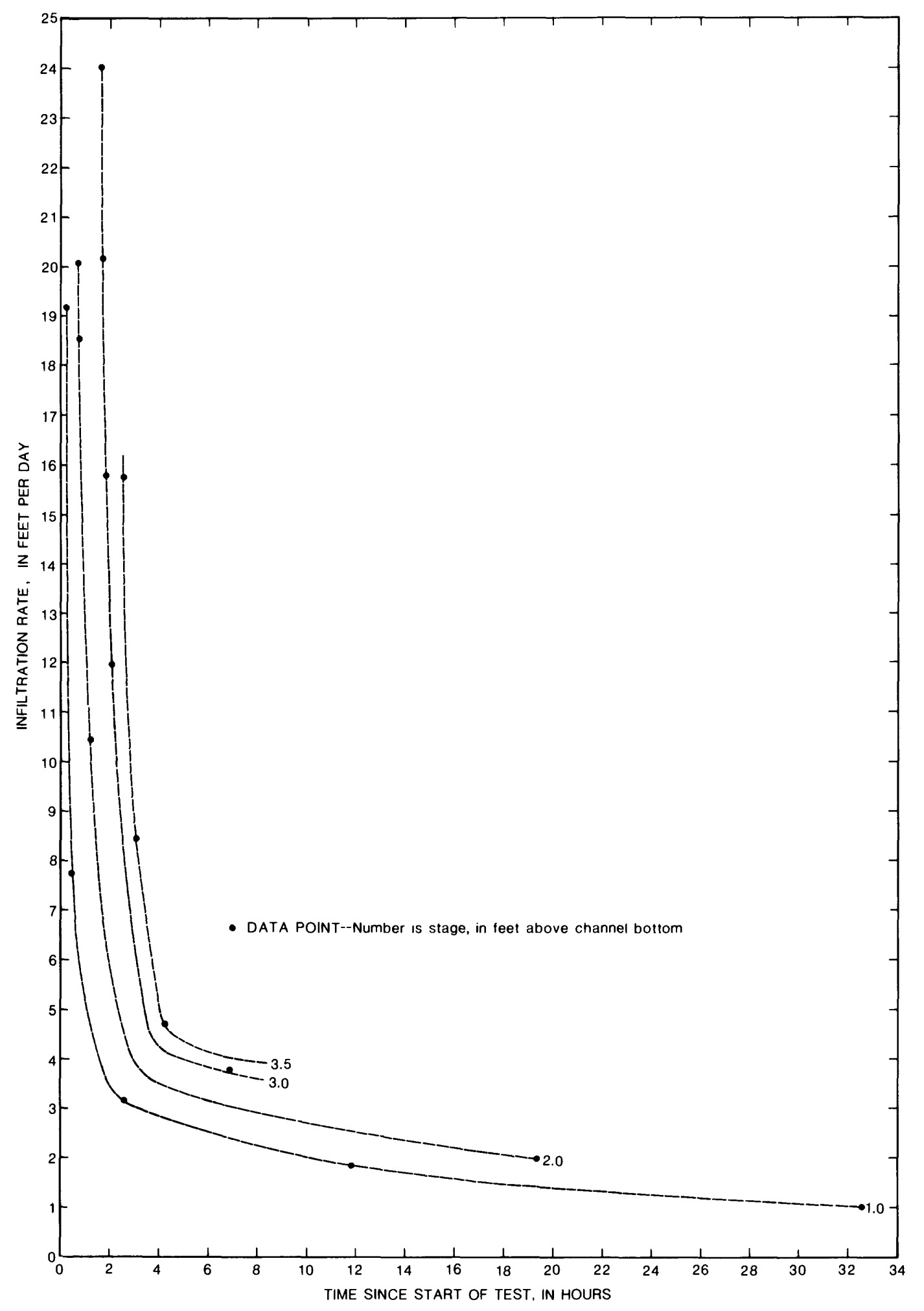

Figure 18. Infiltration rate as a function of stage and time in channel infiltrometer during test 1 at site 3. 


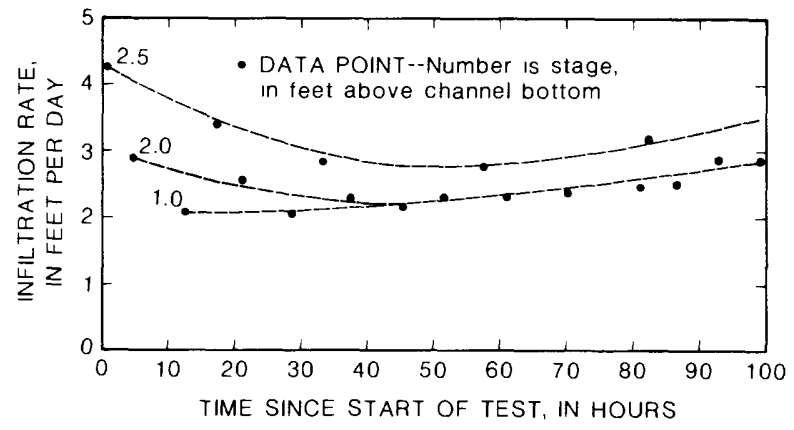

Figure 19. Infiltration rate as a function of stage and time in channel infiltrometer during test 2 at site 3.

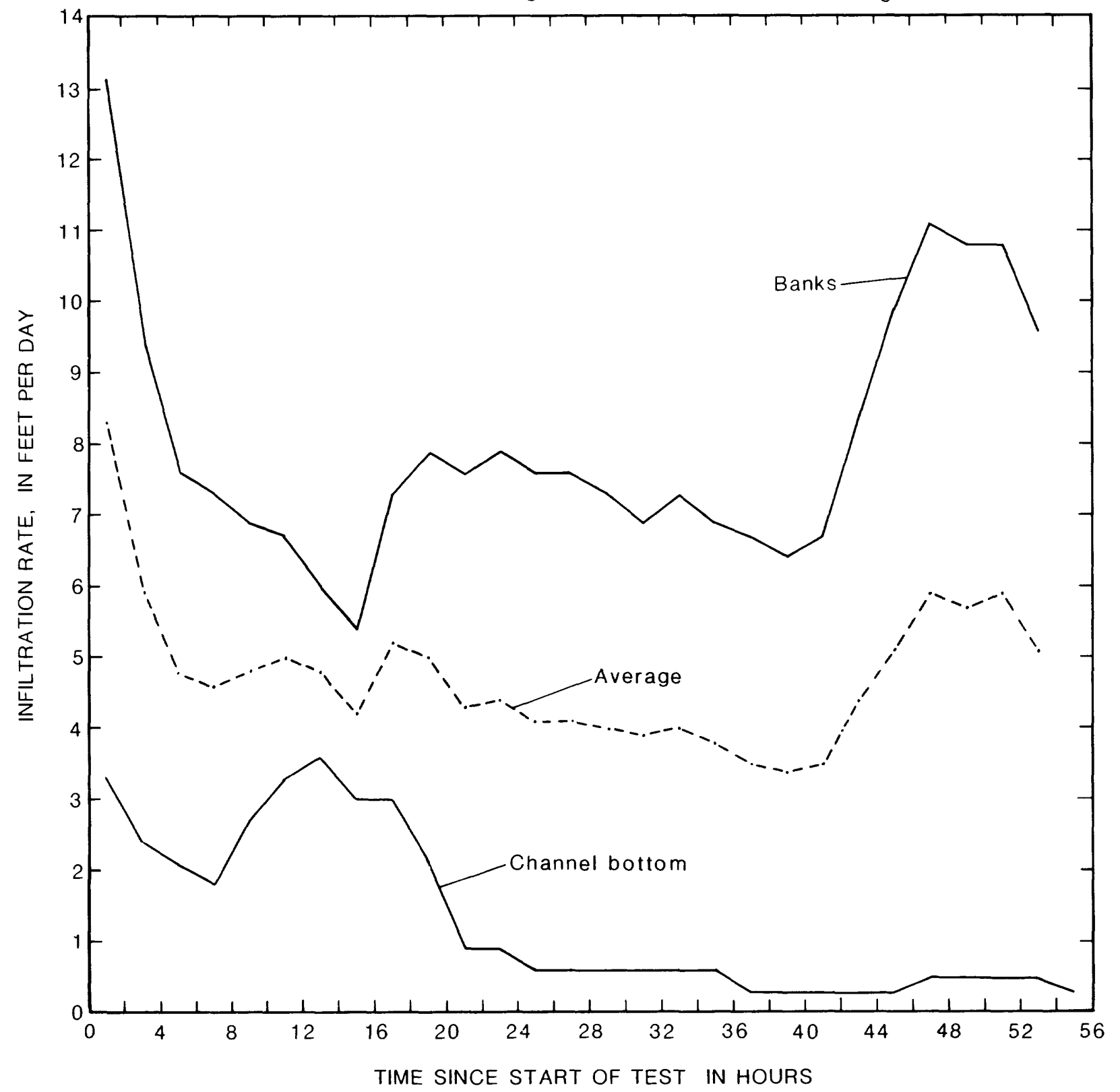

Figure 20. Infiltration rate for double-ring infiltrometers at site 3 . 
at site 2 , the average soil conditions were represented equally by both types of infiltrometers.

\section{Pawnee River Near Kalvesta}

\section{Site Description}

Site 4 on the Pawnee River is in the NE1/4 SE1/4 NW1/4 sec. 16, T. 23 S., R. 29 W., near Kalvesta in Finney County, on land owned by D.D. Stearns. The area of the drainage basin upstream from the site is $\mathbf{5 9 . 6}$ square miles. The Pawnee River's ephemeral channel is incised into the narrow flood plain of the upper Pawnee River valley and is about 30 feet wide and about 4 feet deep (fig. 21). The valley alluvium is about 20 feet thick and consists of fluvial silt, clay, and sand (fig. 21). The water table is about 4 feet below the bottom of the channel.

The channel infiltrometer was constructed by placing two wooden cofferdams 12 feet apart across the channel of the Pawnee River. One 4inch diameter potentiometer (P1) was installed in coarse sand at 5 feet below the bottom of the channel and 1 foot below the water table (fig. 21). The water level in $P 1$ was recorded continuously by a float-activated graphical recorder. The water level in the channel infiltrometer was measured by a continuous float-activated graphical recorder in a 10-inch diameter stilling well.

\section{Infiltration Tests}

Infiltration test 1 at site 4 started at 1015 hours on May 8,1986 , to simulate recharge during an uncontrolled floodflow. Water was discharged into the channel infiltrometer by gravity flow from a 8,400-gallon steel storage tank, which was filled by tank truck with ground water from the Garden City public-water supply. The channel infiltrometer was filled as previously described to a depth of 3.3 feet (fig. 22). Then for 7 hours the water level was allowed to decline about 0.2 foot and again raised to 3.3 feet. After this time, the filling was discontinued. Test 1 continued for 31 hours (fig. 22). The water level in $P 1$ rose to within 0.2 foot, but never reached, the bottom of the channel (fig. 22).

The infiltration rate was calculated using the channel-infiltrometer method previously described and was plotted as a function of the

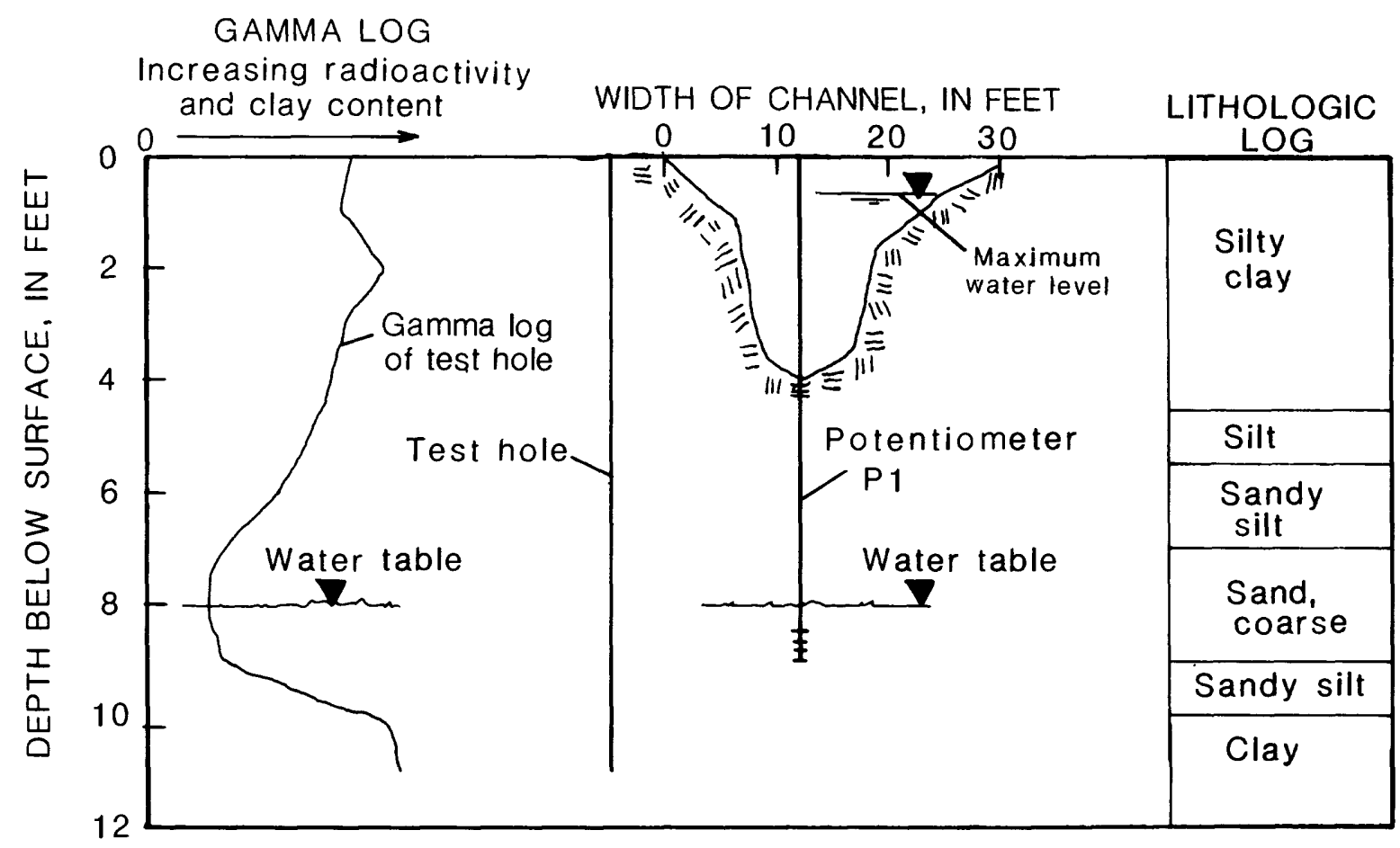

Figure 21. Gamma and lithologic logs, channel configuration, and location of test hole and potentiometer at site 4. 


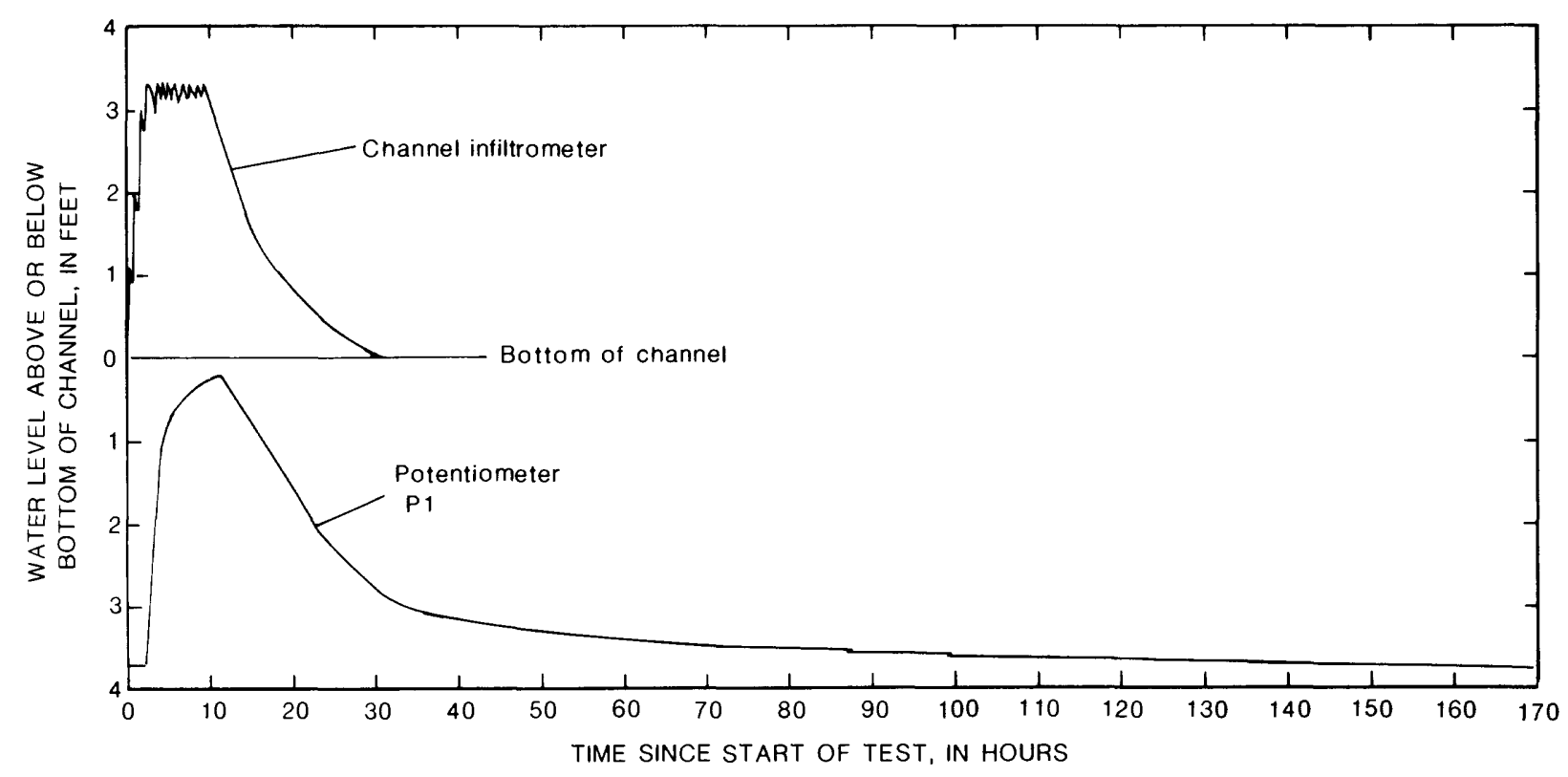

Figure 22. Water level in channel infiltrometer and potentiometer during test 1 at site 4 .

stage and time since the start of test 1 (fig. 23). The infiltration rate initially was rapid, with the higher stages producing the more rapid rate. Even though the infiltration rate decreased with time, it still was influenced by stage. Because the temporary ground-water mound did not intersect the bottom of the channel, the hydraulic conductivity of the channel bed material probably is controlling the infiltration rate.

Infiltration test 2 started at 0945 hours on May 15,1986 , to simulate recharge during a controlled floodflow or peak. Water was discharged into the channel infiltrometer from the same source as test 1 ; however, a 3 -inch float valve was used to maintain the water level in the channel infiltrometer at a relative constant 1.55 feet (fig. 24). Test 2 continued for 43 hours at which time all the water in the storage tank had drained into the channel infiltrometer. The water level in $P 1$ rose to within 0.6 foot, but never reached, the bottom of the channel (fig. 24).

The infiltration rate for test 2 was calculated from the decline of the water level in the storage tank during test 2 . The infiltration rate was plotted as a function of time since the start of test 2 (fig. 25).

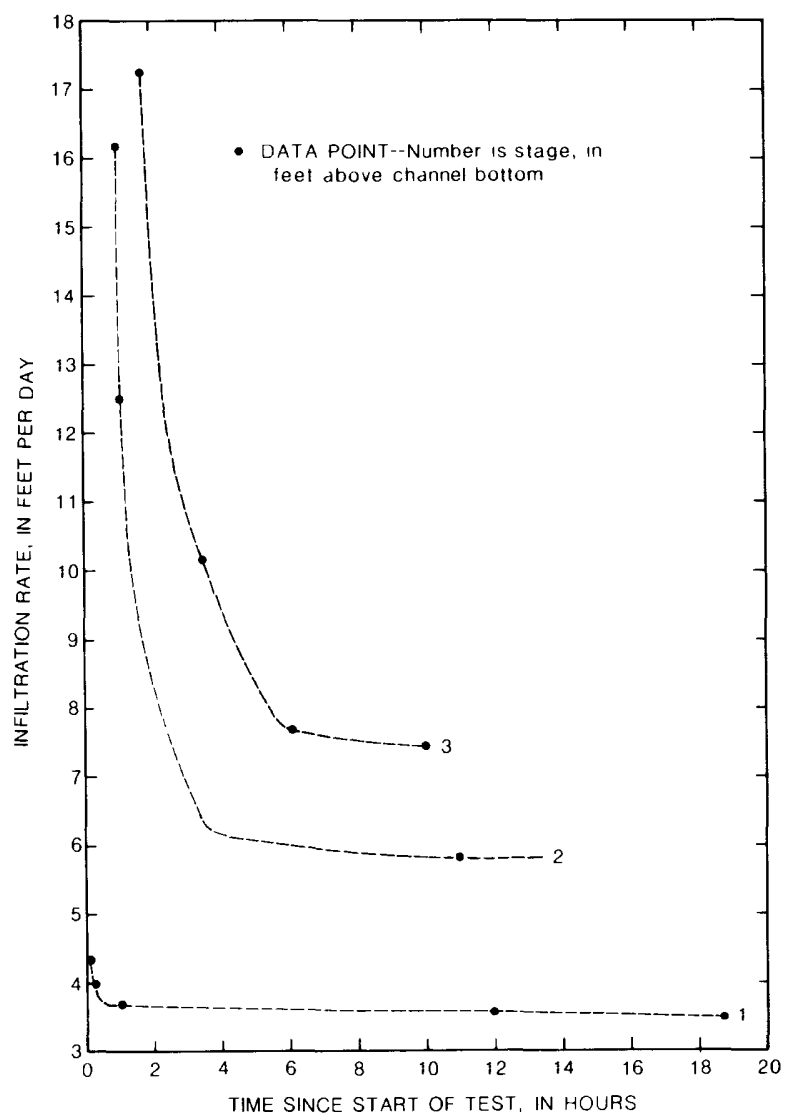

Figure 23. Infiltration rate as a function of stage and time in channel infiltrometer during test 1 at site 4 . 


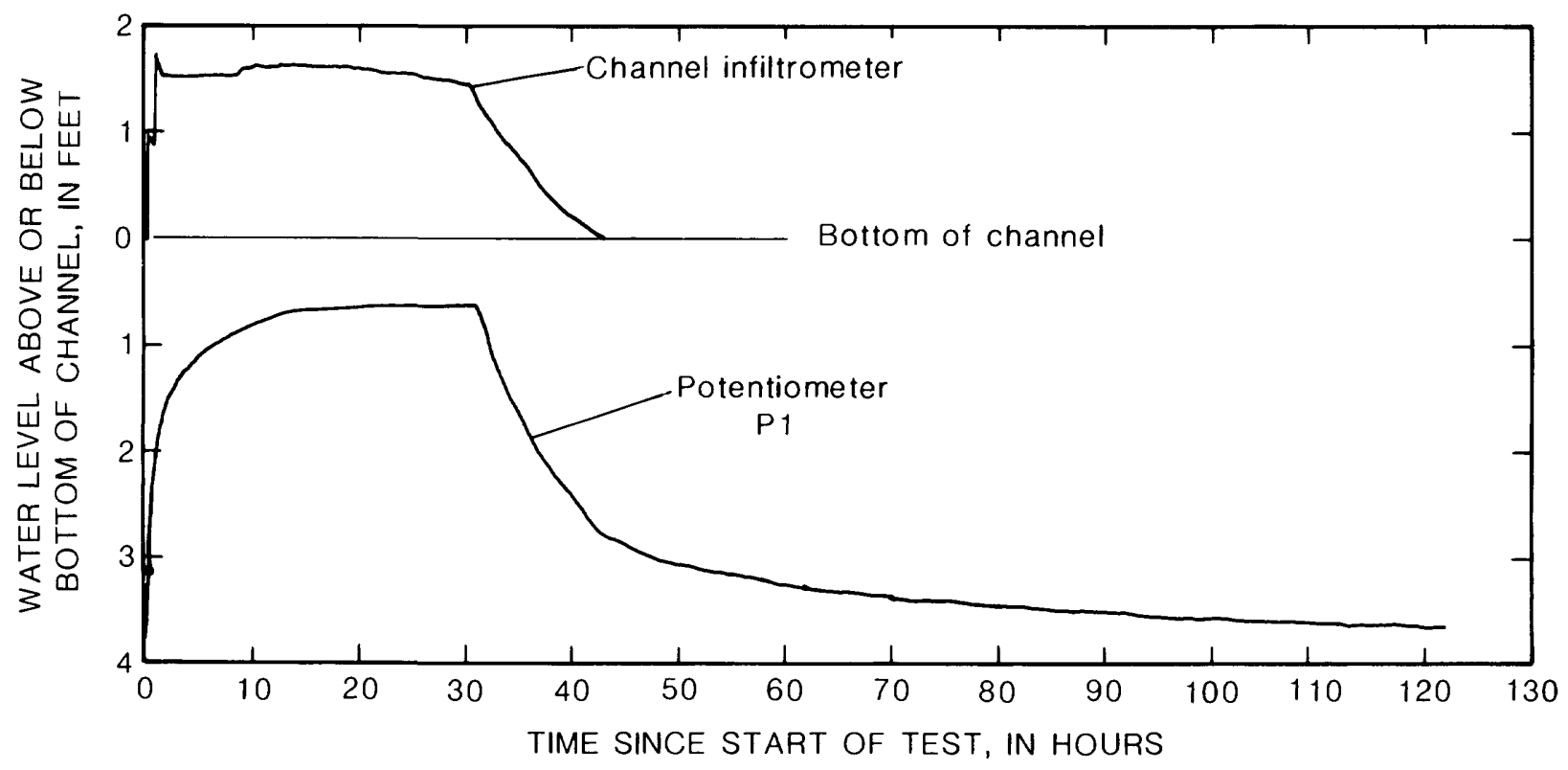

Figure 24. Water level in channel infiltrometer and potentiometer during test 2 at site 4.

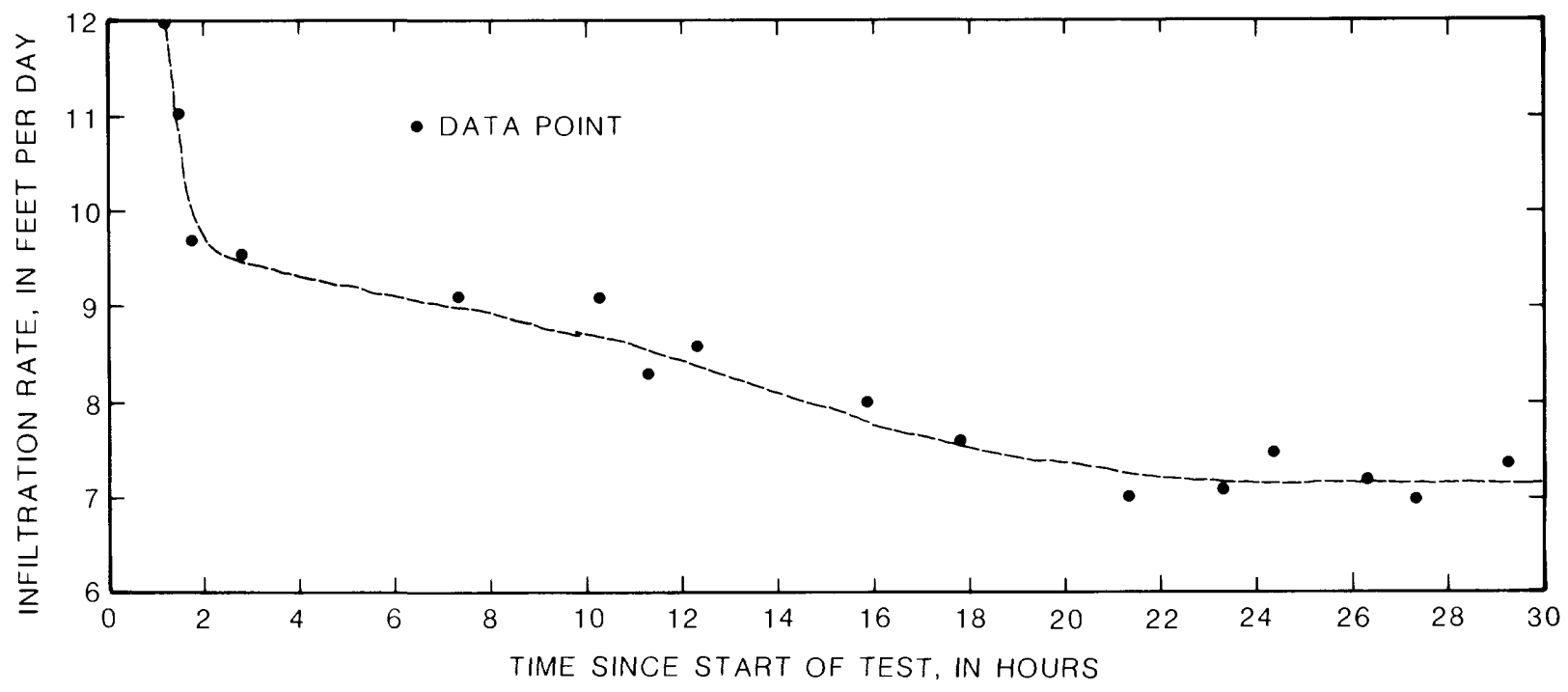

Figure 25. Infiltration rate in channel infiltrometer durmg test 2 at site 4 .

Double-ring infiltrometers were placed in the bottom and in the bank of the channel as previously described. The infiltration rate was less than 0.2 foot per day as compared to 7 to 12 feet per day in the channel infiltrometer. There were no visible macropores at the double-ring infiltrometer sites where the soil had been compacted by cattle. In the channel infiltrometer, the soil had not been compacted as much by cattle because of the steep channel banks.

\section{Duck Creek Near Dodge City}

\section{Site Description}

Site 5 on Duck Creek is in the SW 1/4 SW 1/4 NW1/4 sec. 3, T. 26 S., R. 25 W., near Dodge City in Ford County, on land owned by W.W. Adams. The area of the drainage basin upstream from the site is 10.2 square miles. Duck Creek's ephemeral channel is incised into the alluvium of the Ogallala Formation and is about 30 feet 
wide and 4 feet deep (fig. 26). The alluvium is about 75 feet thick and consists of silt, sand, and some clay (fig. 26). The water table is about 42 feet below the bottom of the channel. In the bottom of the channel there is a deposit of compacted clayey silt. The apparent moisture content before the infiltration tests ranged from about 19 to 25 percent (fig. 26).

The channel infiltrometer was constructed by placing two wooden cofferdams 6 feet apart across the channel of Duck Creek. One 4-inch diameter potentiometer (P1) was installed at 3 feet below the bottom of the channel just above a clayey silt layer (fig. 26). The water level in P1 was recorded continuously by a float-activated graphical recorder. A neutron-probe access tube was installed in an access hole hand augered to 5 feet below the bottom of the channel (fig. 26). The bottom of the neutron-probe access tube was kept unplugged so that it could be used as a potentiometer (P2). The water level in P2 was measured manually with a steel tape. The water level in the channel infiltrometer was measured by a continuous float-activated graphical recorder in a 10 -inch diameter stilling well.

\section{Infiltration Tests}

Infiltration test 1 started at 1000 hours on May 23, 1986, to simulate recharge during an uncontrolled floodflow or peak. Water was discharged into the channel infiltrometer by gravity flow from a 8,400-gallon steel storage

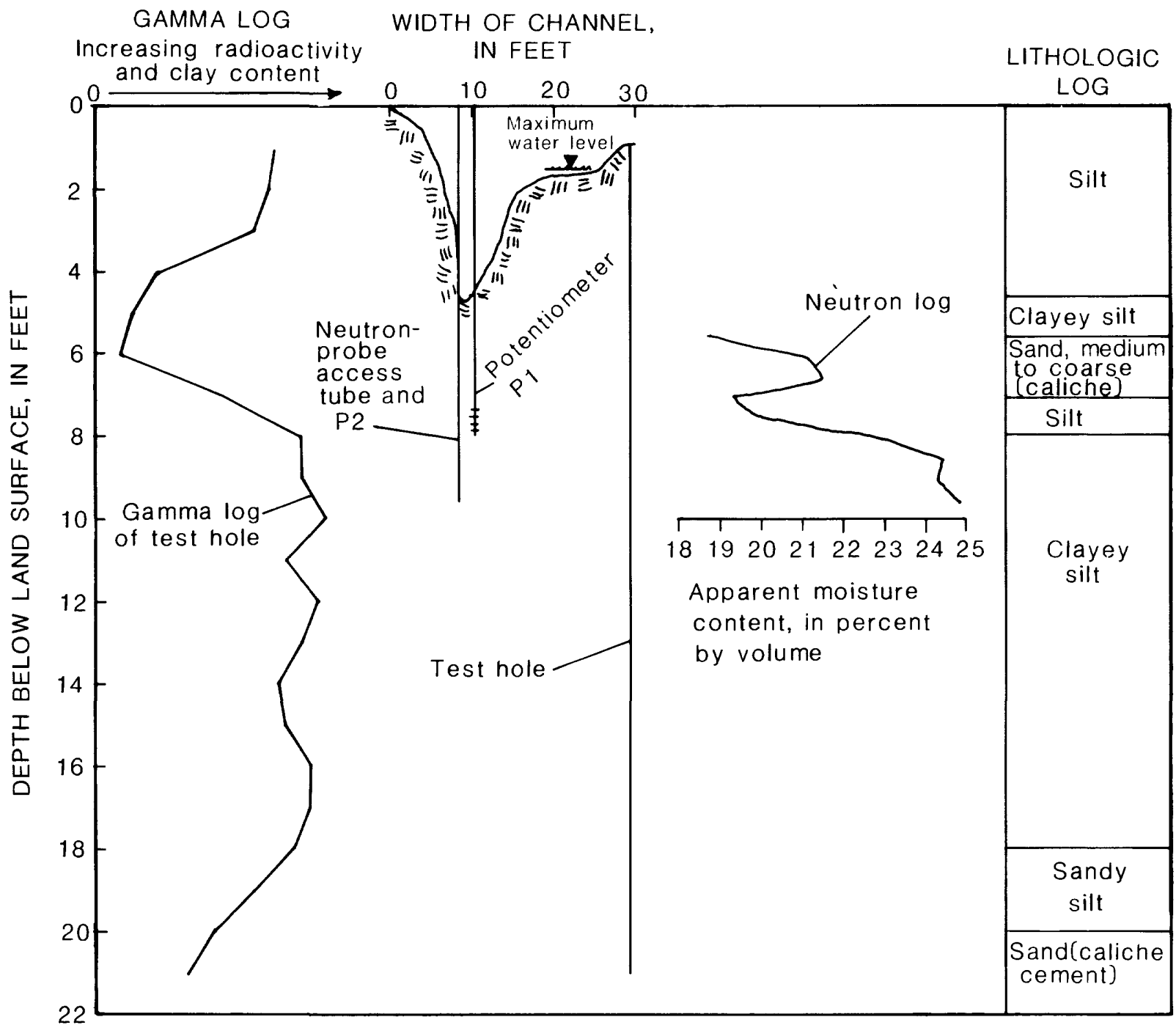

Figure 26. Gamma, neutron, and lithologic logs, channel configuration, and location of test hole, potentiometers, and neutron-probe access tube at site 5 . 
tank, which was filled by tank truck with ground water from the Dodge City public-water supply. The channel infiltrometer was filled as previously described to a depth of 3.2 feet (fig. 27). Test 1 continued for 86 hours (fig. 27). No water was detected in either P1 or P2. An apparent change in moisture content of about 1 to 6 percent occurred during the test (fig. 28). Figure 28 also shows the progression of the wetting front during test 1 .

The infiltration rate was calculated using the channel-infiltrometer method previously described and was plotted as a function of stage and time since the start of test 1 (fig. 29). The initial infiltration rate decreased to a relatively constant 1 foot per day after 6 hours. The hydraulic conductivity of clayey silt layer just below the bottom of the channel probably is controlling the infiltration rate. Also, the bottom and upper banks of the channel had been puddled or compacted by cattle.

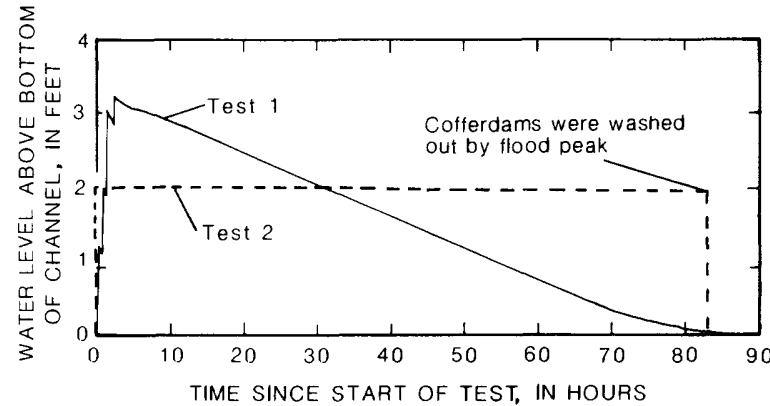

Figure 27. Water level in channel infiltrometer during tests 1 and 2 at site 5 .

Infiltration test 2 started at 1300 hours on May 28, 1986, to simulate recharge during a controlled floodflow or peak. Water was discharged into the channel infiltrometer from the same source as test 1 ; however, a 3 -inch float valve was used to maintain the water level in the channel infiltrometer at a relative constant 2 feet (fig. 27). Test 2 continued for 83 hours or

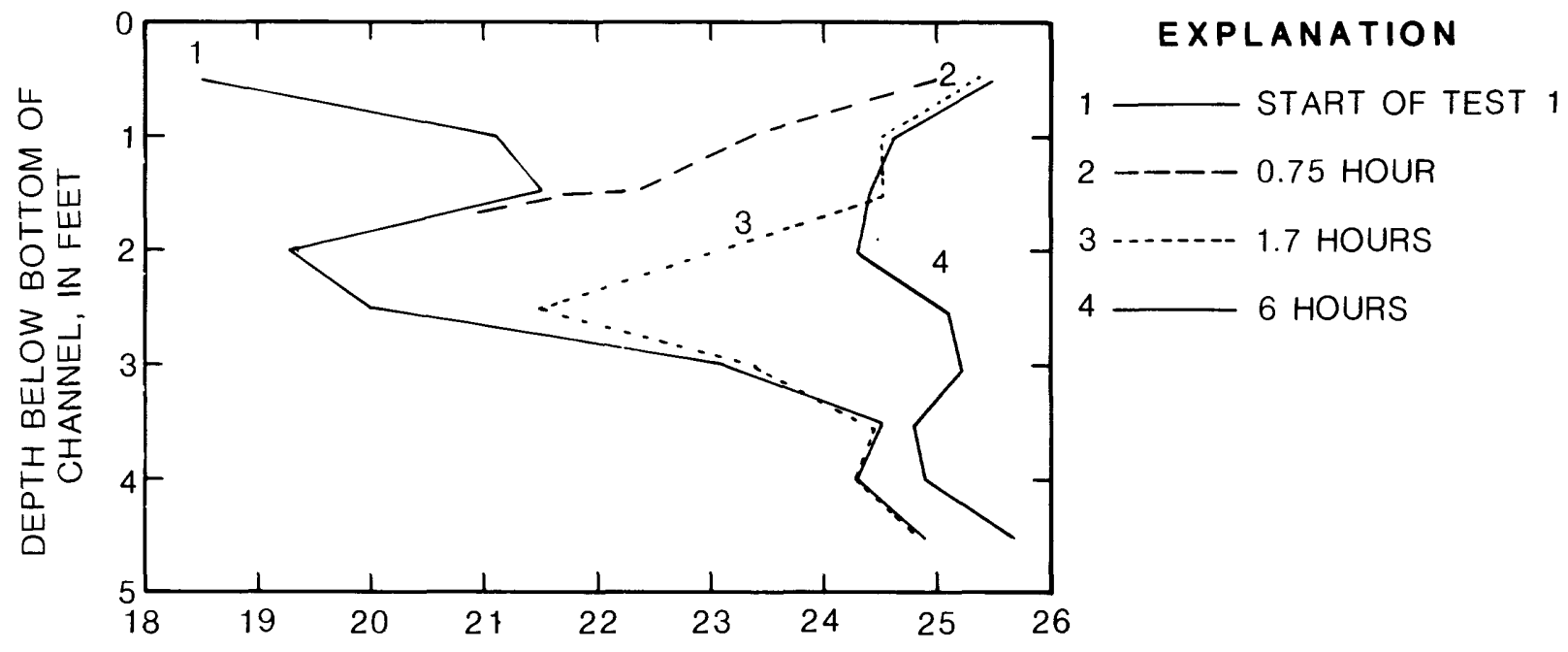

APPARENT MOISTURE CONTENT, IN PERCENT BY VOLUME

Figure 28. Neutron logs from neutron-probe access tube at site 5 .

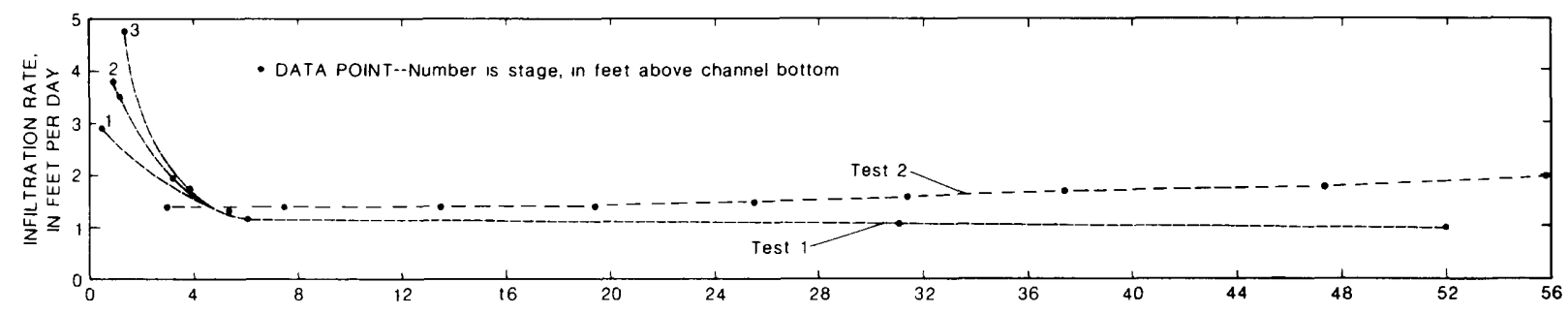

Figure 29. Infiltration rate as a function of stage and time in channel infiltrometer during test 1 and 2 at site 5. 
about 3.5 days until a flood peak washed out the channel infiltrometer. No water was detected in either P1 or P2. The compacted clayey silt in the bottom of the channel probably was the restricting layer, with most of the water moving horizontally into the steep silt banks. The infiltration rate during test 2 ranged from 1.4 feet per day after 3 hours from the start of the test to 1.9 feet per day after 54 hours (fig. 29).

Double-ring infiltrometers were placed in the bottom and in the bank of the channel as previously described. Comparison of infiltration- rate values from the channel and double-ring infiltrometers (fig. 30) was fair and supports the hypothesis of predominantly horizontal flow from the channel infiltrometer. The infiltration rate in the double-ring infiltrometer in the channel was only 0.15 foot per day, while the average rate on the silty bank was approximately 0.40 foot per day.

\section{Comparison of Sites}

In general, the infiltration tests at five selected sites in the Pawnee River basin indicate a great variability in infiltration rate. The infiltration rate is dependent on the following factors: (1) the lithology of the unsaturated zone underlying the channel, (2) the stage or depth of water in the channel, (3) depth to the water table, (4) condition of the bottom and sides or banks of the channel (compaction of soil surface, type and amount of vegetation, and so forth) and (5) antecedent soil-moisture conditions.

The lithology of the unsaturated zone is the most important factor in determining the infiltration rate. The absence or presence of tight or restrictive layers determines the rate at which water can percolate downward in the unsaturated zone. If percolating water is perched temporarily above a restrictive layer and a ground-water mound intersects the bottom of the channel, the infiltration rate of water infiltrating through the wetted perimeter will decrease. This phenomenon probably was responsible for the decrease in the infiltration rate after the initial rapid rate at sites 1 and 2 . After the temporarily perched ground-water mound reached the bottom of the channel, varying stage had little effect on the recharge at the two sites. Sites 1 and 2 are in the eastern part of the Pawnee River basin where, in

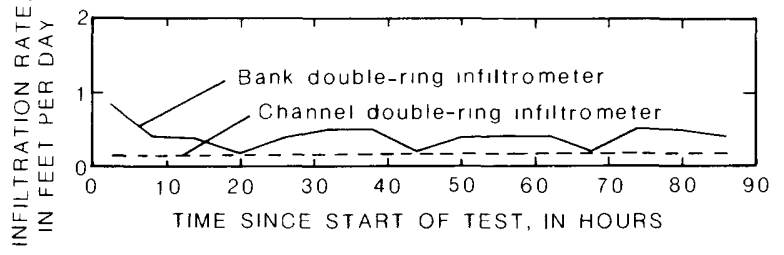

Figure 30. Infiltration rate for double-ring infiltrometers at site 5 .

general, there is more clay and silty clay and the area receives more precipitation.

When the water percolates downward as unsaturated flow, the bottom of the channel along the wetted perimeter is the restricting layer, and the infiltration rate will be directly proportional to any change in stage or depth of water in the channel. This phenomenon was observed in the early or initial times at all the sites and at the later times during the infiltration tests at sites 3 and 4 .

If a ground-water mound builds up on the water table to intersect the bottom of the channel, a decrease in infiltration rate will be the same as previously discussed for perched mounds. This phenomenon was not detected at any of the sites. However, if the channel infiltrometer at site 4 had been operated much longer, the ground-water mound probably would have reached the bottom of the channel, slowing the infiltration rate.

For the low-stage tests at sites 2, 3, and 5, the infiltration rate increased slowly with time. This probably can be attributed to elimination of entrapped air, which would tend to increase the hydraulic conductivity.

The condition of the bottom of the channel can have a significant effect on infiltration rate. If the channel bottom and banks are covered with grass and weeds and there is good earthworm activity in the soil, permeability of the channel bottom will increase considerably. Greater biotic activity, excluding the large herbivores, increases the number of macropores in the soil, which in turn enhance infiltration. If the bottom and banks are devoid of vegetation and livestock have puddled or compacted the soil, or fine-grained sediment has been deposited, the permeability of the soil can be reduced significantly. Sites 1,3 , and 4 had 
vegetation and no compaction due to livestock, and the infiltration rate was more rapid at these three sites. Sites 2 and 5 were devoid of vegetation, and livestock had compacted the bottom of the channel; consequently, the infiltration rate was less rapid.

If the channel has had flow recently, the initial infiltration rate will be slower because the soil particles have already swelled to a greater degree than under dry conditions. This phenomenon was detected at the start of the second infiltration test at sites $1,3,4$, and 5 .

\section{ESTIMATED CHANNEL INFILTRATION FROM SIMULATED FLOODFLOWS}

An estimate of channel infiltration from floodflows was made to evaluate the effect of flood-retarding structures within the Pawnee River basin. Natural floodflows on the tributaries within the Pawnee River basins are typically high-peak, short-duration flows. Nearly all of the tributaries and most of the length of the main streams of the basin are ephemeral or intermittent, having virtually no base flow. Streamflow is dependent on intense rainstorms that can occur at any time during the year.

\section{Simulated Flood Hydrographs}

The five sites were chosen to represent various channel conditions encountered throughout the basin. Floodflow infiltration was estimated for each site by using infiltrationstage-duration curves developed from the channel-infiltration experiments (figs. $7,12,18$, $19,23,24$, and 29). Additional information needed for this analysis consisted of stagedischarge relations, peak discharge, and flow duration of typical floodflows at each site. Floodhydrograph shapes for both controlled and uncontrolled floodflows were developed from streamflow records and were used to simulate flood discharges and durations for each site.

A stage-discharge relation was developed for each site by using the U.S. Geological Survey's Water Surface PROfile program, WSPRO (Shearman and others, 1986). Data used in this program included channel cross sections obtained from the channel-infiltrometer profiles, channel slopes determined from $7-\frac{1}{2}$ minute topographic quadrangles, and channel roughness coefficients estimated from onsite inspection and photographs of each site.

Uncontrolled flood hydrographs at the five sites were developed from data collected at Guzzlers Gulch near Ness City (station number 07140700 , fig. 1), a continuously gaged stream within the Pawnee River basin. This station has a drainage area of 58.2 square miles located in the north-central part of the Pawnee River basin. From 1962 to 1973, Guzzlers Gulch was completely uncontrolled. Three flood-retarding structures were constructed from 1973 to 1976, affecting approximately one-half of the drainage area. Controlled streamflow records were available from 1976 to 1980 when gaging operations were discontinued.

Two types of hydrographs were considered in the infiltration analysis. The first was an uncontrolled single peak flow, having a duration dependent on the magnitude of the peak. The second type was a controlled, triangular-shaped hydrograph that had the same flood volume as the uncontrolled flow, but a smaller peak flow and longer duration.

Fifteen floodflow hydrographs for Guzzlers Gulch from 1962 to 1973 were used to generate a best-fit curve of peak discharge versus flood duration (fig. 31). Flood durations for uncontrolled floodflows at the five sites were generated from this curve. An average hydrograph shape was drawn subjectively by using the shapes of the 15 selected hydrographs. The rising stage of the hydrograph, on the average, was one-eighth of the total flood duration.

Two uncontrolled flood hydrographs were developed for each site. The peak discharge of the first hydrograph was determined from the maximum stage attained during the infiltration graph was one-half of the first. Flood volume was determined by summing the discharge for the duration of each flood hydrograph. The peak discharge of the controlled flood hydrographs was based on equation 1 for a triangular-shaped hydrograph and a relation between controlled and uncontrolled floodflow durations: 
Flood volume $=\left(\frac{1}{2}\right) \times($ peak discharge $)$

$x$ (flood duration).

The controlled durations were assumed to be four times longer than the uncontrolled durations. This difference was determined from flood hydrographs developed by the U.S. Soil Conservation Service for locations with the Pawnee River basin and also was supported by the single hydrograph available from Guzzlers Gulch streamflow record after the floodretarding structures were built.

By knowing the volume and flood duration of the uncontrolled floodflow, the peak discharge of the controlled peak could be determined by equation 2 :

Peak discharge (controlled) $=2 \times$ (volume $) /$ [4 x flood duration (uncontrolled)].

The controlled floodflow hydrograph was drawn with the same rising stage as the uncontrolled flood hydrograph until the peak discharge was obtained. The controlled recession stage was determined to be a constant decline in discharge to zero flow and a total flow duration four times the uncontrolled duration. The relation between uncontrolled and controlled flood hydrographs for two sites is shown in figure 32 .

The controlled-and uncontrolled-discharge hydrographs were converted to stage hydrographs, and infiltration was computed for each time step and for each stage. The total amount of water infiltrated was summed over the duration of each simulated floodflow. This procedure was repeated, using one-half the uncontrolled peak discharge for each site. The result was flood hydrographs that had shortened durations, lowered stages, and reduced flood volumes. These factors combined to reduce the infiltration volume. Each site comparison of these two flood volumes gave an indication of the channel's infiltration response as flood volumes increased. The results are shown in table 1.

Cumulative infiltration from simulated floodflows at the five sites varied from 1.3 to 15 percent of the uncontrolled flood volumes and 1.2 to 31 percent of the controlled flood volumes. Controlled simulated floodflows resulted in an approximate 2-percent increase in infiltration in comparison to infiltration during uncontrolled

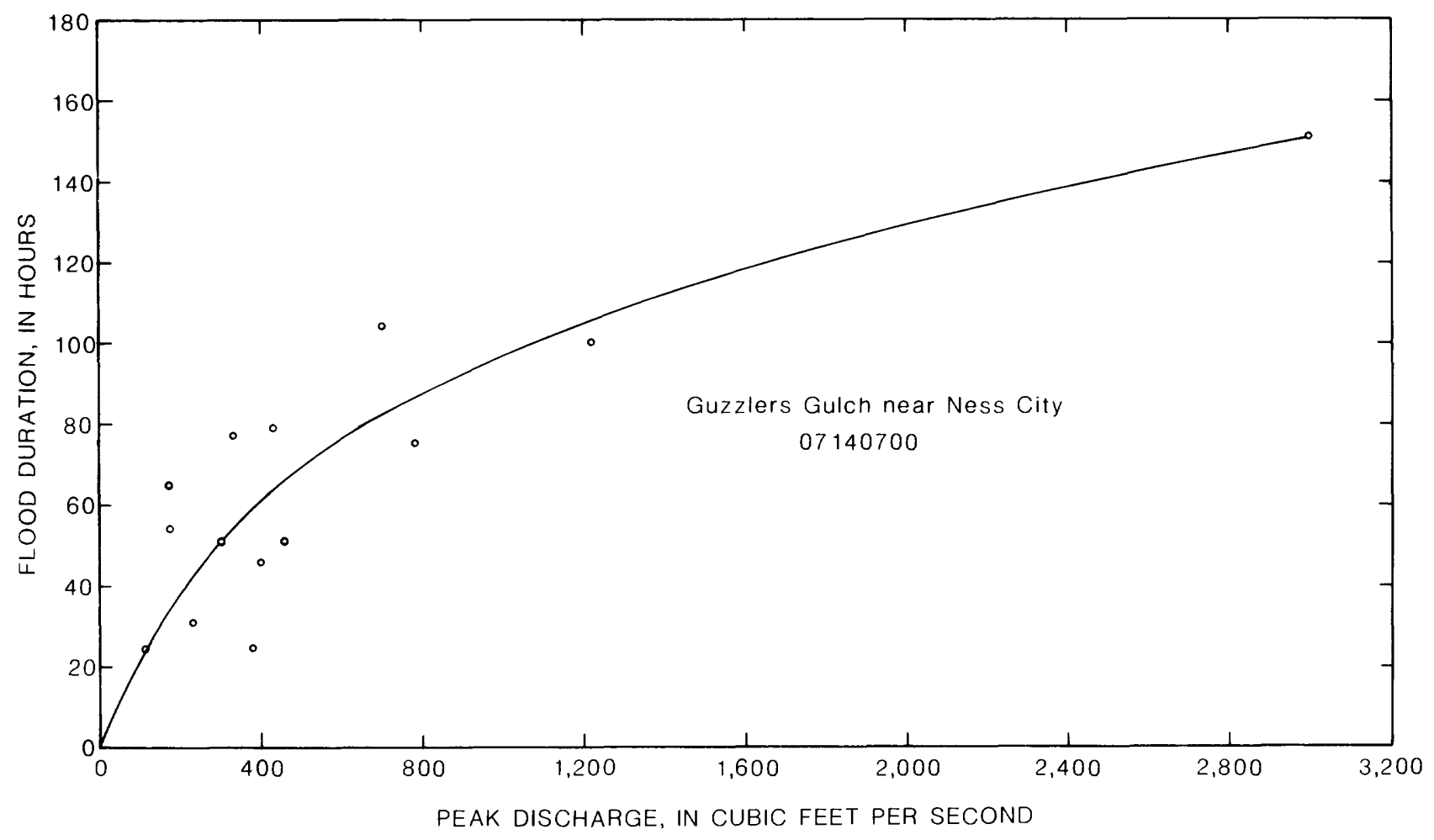

Figure 31. Flood duration-peak discharge relation for Guzzlers Gulch near Ness City, station number 07140700. 
flows, with a variance of -4.7 to 16 percent.

\section{Results}

A plot of simulated flood volume as a function of calculated cumulative infiltration is shown in figure 33 . It depicts the relative differences in infiltration between the sites. Site 4 had the greatest increase of cumulative infiltration from uncontrolled to controlled floodflows, followed by site 1 . Sites 2 and 5 showed mixed results, with increased infiltration for the smaller controlled floodflows switching to increased infiltration for the larger uncontrolled flows. Site 5 showed increased infiltration for uncontrolled flows. When all simulated floodflows are considered, an average of 6.9 percent of the uncontrolled floodflow volumes were infiltrated, and an average of $\mathbf{9 . 1}$ percent of the controlled volumes, an average increase of 2.2 percent. The range was a 16.0 percent increase at site 4 to a 4.7 -percent decrease at site 3 (table 1).

\section{CONCLUSIONS}

Infiltration tests were conducted in channels of the Pawnee River and its tributaries at five sites. The sites were selected to represent different channel types, geomorphology, unsaturated-zone lithology, depth to the water table, and geographical area within the Pawnee River basin. An infiltration rate was determined at each site using the channelinfiltration method. A short section of an ephemeral channel was isolated with two cofferdams, creating a channel infiltrometer. Therefore, the infiltration rate determined for these sites represents an integration of the infiltration-rate values of water moving through the bottom and sides or banks of the channel.

Channel infiltration rates in the Pawnee River basin are quite variable from one location to another and are dependent on several factors. Lithology of the unsaturated zone appears to be the most important factor. Condition of the

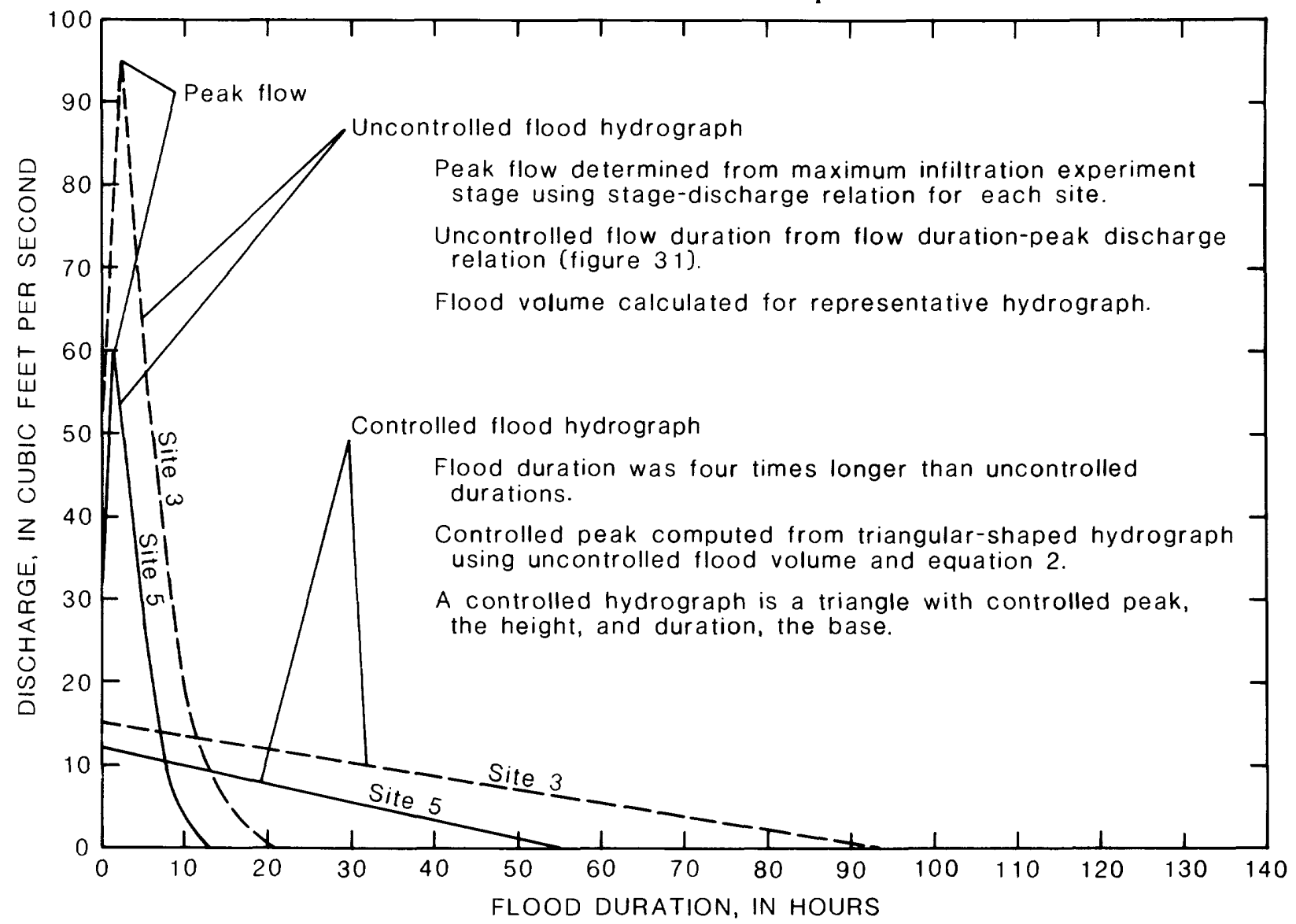

Figure 32. Relation between uncontrolled and controlled flood hydrographs for sites 3 and 5 . 


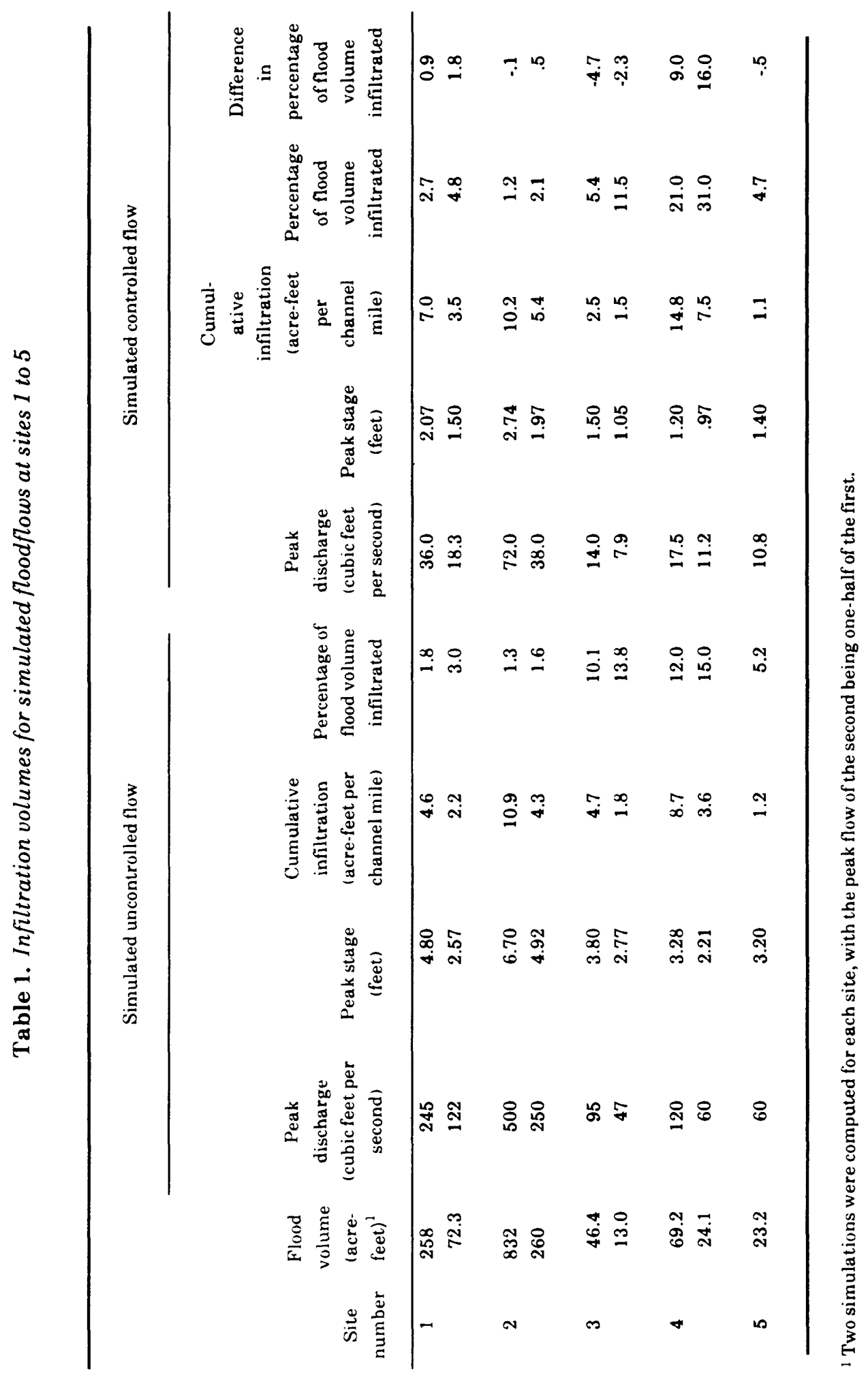




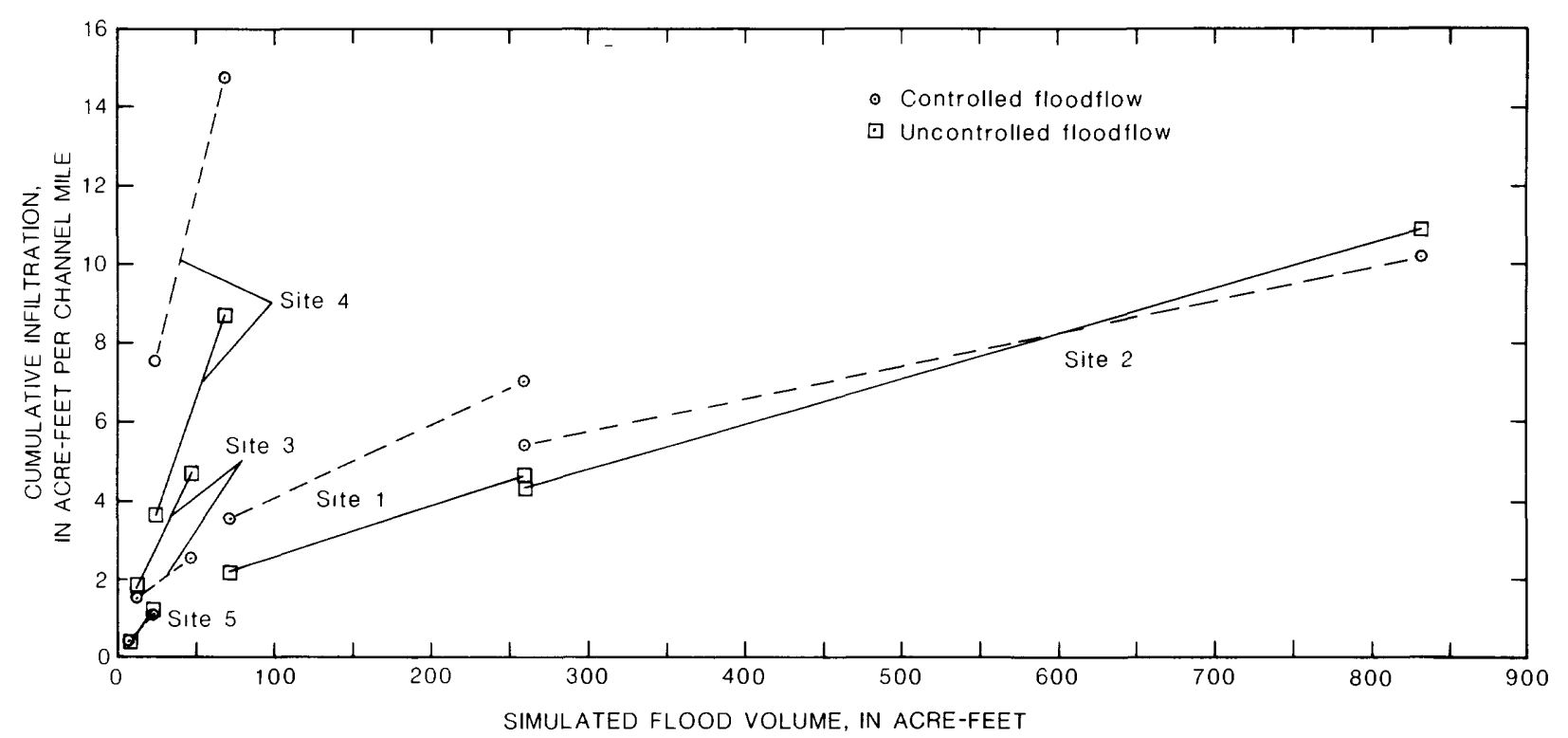

Figure 33. Cumulative infiltration along channel at sites 1 to 5 as a function of simulated flood volumes.

bottom of the channel is also very important. Greater biotic activity, excluding livestock, increases the number of macropores in the soil, which in turn enhance infiltration. Also, infiltration is directly proportional to the stage or depth of water in the channel. Depth to the water table, either the regional or temporarily perched saturated zone, can affect the infiltration rate by creating a ground-water mound that intersects the channel bottom.

The use of double-ring infiltrometers to accurately determine channel-infiltration rates depends upon locating the infiltrometers at a site representative of the average conditions along and across the channel, including the steep banks. Macropores are very important in conveying water downward, and their presence or absence in the very small area of a doublering infiltrometer can affect the resulting measurements by several orders of magnitude. Also, double-ring infiltrometers would have to be used only under suitable lithologic conditions because the double-ring infiltrometers measure only vertical infiltration, whereas some channel infiltration can occur horizontally. The correlation of the infiltration rates from the channel and double-ring infiltrometers ranged from good at most sites to very poor at one site.

Using this infiltration-rate data, cumulative infiltration from flood hydrographs and from those hydrographs modified by a floodwaterretarding structure was calculated. Cumulative infiltration from simulated floodflows at five sites varied from 0.4 to 10.9 acre-feet per mile of channel and from 1.3 to 15 percent of total flood volume for uncontrolled floodflows. Controlled floodflows varied from 0.5 to 14.8 acre-feet per channel mile of cumulative infiltration and from 1.2 to 31 percent of the controlled flood volume. Controlled simulated floodflows resulted in an approximately 2 -percent increase in infiltration over the uncontrolled flows.

This study determined infiltration rates in ephemeral channesl without regard to suspended sediment; therefore, these infiltration rates may be larger than for natural floodflows. Ground-water-recharge rates probably will be less than these infiltration rates because some of the infiltrated water will be lost to evapotranspiration and soil retention.

\section{REFERENCES CITED}

Bouwer, Herman, 1962, Field determinations of hydraulic conductivity above a water table with the double-tube method: Proceedings of Soil Science Society of America, v. 26, 1962, p. 330-335.

Fenneman, N.M., 1946, Physical divisions of the United States: U.S. Geological Survey map, scale $1: 7,000,000,1$ sheet. 
National Oceanic Atmospheric Administration, 1985, Climatological data for Kansas-Annual summary, 1985: Washington, D.C., U.S. Department of Commerce, v. 99, no. 13, $34 \mathrm{p}$.

Shearman, J.O., Kirby, W.H., Schneider, V.R., and Flippi, H.N., 1986, Bridge waterways analysis model/research report: Federal
Highway Administration Report FHWA/RD-86/108, $112 \mathrm{p}$.

Sophocleous, M.A., and Perry, C.A., 1987, Measuring and computing natural groundwater recharge at sites in south-central Kansas: U.S. Geological Survey WaterResources Investigations Report 87-4097, 48 p. 